\title{
KVALITETA PITANJA I USPJEH SREDNJOŠKOLSKIH SUDIONIKA NATJECANJA IZ BIOLOGIJE U ZNANJU
}

\author{
Ines Grgurić ${ }^{1}$, Valerija Begić2, Marijana Bastić3 \\ ${ }^{1}$ X. gimnazija "Ivan Supek“, Klaićeva 7, Zagreb \\ igrguric12341@gmail.com \\ 2 Osnovna škola Sesvetski Kraljevec, Školska 10, Zagreb \\ ${ }^{3}$ Osnovna škola Rudeš, Jablanska 51, Zagreb \\ ${ }^{4}$ Gimnazija Josipa Slavenskog Čakovec, V, Nazora 34, Čakovec \\ ${ }^{5}$ Biološki odsjek Prirodoslovno matematičkog fakulteta Sveučilišta u Zagrebu, Rooseveltov trg 6, Zagreb
}

\section{SAŽETAK}

Biologija je već niz godina među najzastupljenijima izbornim predmetima na Državnoj maturi pa se sukladno tome veliki broj učenika uključuje i na natjecanja iz biologije. Na županijskom natjecanju kao 20 \% najuspješnijih po županijama izlučeno je 362 učenika srednjih škola, čiji su postignuti rezultati pri rješavanju pisane provjere analizirani s ciljem utvrđivanja povezanosti kvalitativne i kvantitativne analize pitanja. Analiza je provedena u skladu s Nastavnim programom za određeni razred i katalogom za državnu maturu iz biologije kao referentnim točkama konceptualnog okvira i predviđenih ishoda učenja. Pitanja u pisanim provjerama su prihvatljive kvalitete, najkvalitetnija su pitanja kratkog odgovora, a najslabije kvalitete pitanja višestrukog izbora s dva točna odgovora i zadaci povezivanja. Reproduktivni zadaci još uvijek prevladavaju u pitanjima višestrukog izbora i povezivanja, a težina na osnovu riješenosti i procijenjena težina zadataka visoko su povezane. Mala povezanost riješenosti pitanja slabije kvalitete i srednja povezanost kvalitetnijih pitanja s procjenom riješenosti potvrda je kvalitete zadataka i važnosti oblikovanja pitanja uz uvažavanje elemenata procjene kvalitete. Potvrđena bolja povezanost riješenosti i kvalitete pitanja potvrđuje važnost pripreme pitanja uz uvažavanje elemenata procjene kvalitete, a posebno primjene kritičkog razmišljanja u zadacima provjere konceptualnog razumijevanja i sposobnosti rješavanja problema. Rezultati dobiveni analizom u budućnosti se mogu koristiti za poboljšanje izrade pitanja pisanih provjera te razvoj zadovoljavajućih bioloških kompetencija učenika srednjoškolske populacije.

Ključne riječi: kognitivne razine, stručna procjena kvalitete pitanja, natjecanje učenika, iskustvo nastavnika

\section{UVOD}

Istraživanja mnogih autora potvrđuju da se interes učenika za nastavne sadržaje gubi tijekom godina školovanja (George, 2006; Prokop i sur, 2007; Barmby i sur, 2008). Opadanje učeničkog interesa za prirodoslovlje uglavnom dolazi iz zemalja u kojima se prirodoslovlje uči kao integrirani nastavni predmet, a mnogo je manje istraživanja provedeno glede učeničkog interesa za biologiju, kao poseban predmet (Usak i sur, 2009; Garašić, 2012). Hrvatski učenici osmih razreda osnovnih škola biologiju procjenjuju zanimljivom, razmjerno razumljivom i umjereno teškom u odnosu na druge predmete (Marušić, 2006). lako se sadržaj biologije bavi fenomenom života i različitim aspektima življenja, učenici je nisu smjestili na vrh, već negdje u sredinu ljestvice omiljenih predmeta, a kao najčešći razlog neomiljenosti predmeta učenici navode nastavnike (Marušić, 2006). Prema Garašić (2012) interes učenika za prirodoslovlje mijenja se tijekom odrastanja, a ovisi i o spolu. Oba spola su najviše zainteresirana za humanu biologiju, djevojčicama je tema vezana za ljudsko tijelo omiljena, a dječaci kako rastu sve više se odmiču od 
bioloških tema prema fizikalno orijentiranim temama. Postoji opasnost da opći trend pada interesa za izbor prirodoslovnih zanimanja zahvati i studij biologije, posebno zbog ograničenih mogućnosti zapošljavanja biologa izvan prosvjete, što je već dugi niz godina stvarnost hrvatskog tržišta rada (Garašić, 2012).

Nastavnici kontinuirano i sustavno prate postignuća i uspjeh svojih učenika, a kao najbolja metoda provjeravanja učenikovih dostignuća navode se pisane provjere znanja (Cindrić i sur, 2010). Da bi se pisana provjera mogla koristiti kao mjerljivi instrument u praktične svrhe, ona mora biti valjana, objektivna, pouzdana i osjetljiva (Grgin, 1994; Vizek-Vidović i sur, 2003). U pisanim provjerama koje podržavaju osnovna načela pripreme kvalitetnih zadataka svi učenici imaju iste uvjete u kojima mogu postići i ostvariti najbolje rezultate, a oni su odraz njihovog truda, rada i razumijevanja nastavnih tema koje se provjeravaju (De Zan, 2005). Prilikom oblikovanja pisanih provjera osim nastavnih sadržaja, potrebno je unaprijed odlučiti koji će se obrazovni ciljevi i u kojoj mjeri provjeravati. Ako se ne obrati pozornost na smisao i svrhu provjere, može se dogoditi da većinom zadataka provjeravamo samo poznavanje pojedinih činjenica i podataka (Radanović i sur, 2017a), jer se zadaci dopunjavanja najlakše sastavljaju i ocjenjuju (Andrilović i Čudina, 1985). Da bi pisane provjere bile kvalitetno oblikovane potrebno je zahvatiti najmanje tri kategorije ciljeva postignuća prema taksonomskoj klasifikaciji, pri čemu njihov odnos i unutarnje raščlanjene ovisi o prirodi predmeta (Andrilović i Čudina, 1985).

Natjecanja učenika u različitim nastavnim predmetima također je jedan od načina mjerenja postignuća i vještina u odgojno-obrazovnom sustavu. Učenici se na natjecanje iz biologije mogu prijaviti u dvije kategorije, prva kategorija je natjecanje u znanju - učenik pristupa pisanoj provjeri znanja, a druga kategorija je natjecanje učenika u izradi samostalnih istraživačkih radova - učenik predstavlja svoje istraživanje (HBD, 2010). Provjere koje pišu sudionici natjecanja izrađuje Državno povjerenstvo prema Nastavnom programu za gimnazije (MZOŠ, 1995) i udžbenicima koje je odobrilo Ministarstvo znanosti i obrazovanja za tekuću školsku godinu (AZOO, 2014). Treba napomenuti da učenici koji sudjeluju u natjecanju u najvećoj mjeri spadaju u skupinu učenika iznadprosječnih sposobnosti. Zbog toga uzorak natjecatelja čini netipičnu ispitnu populaciju za koju se očekuje bolja riješenost provjera. Ako se u ovoj skupini učenika pojave određeni problemi ili miskoncepcije vezane za rješavanje pitanja iz biologije, poglavito uz ona područja za koja je već dokazano da postoje određene miskoncepcije, za očekivati je da će se te miskoncepcije pojaviti i kod učenika koji su prosječnog uspjeha.

Poželjno je da pisane provjere koje su namijenjene za natjecanja, sadrže različite tipove zadataka kako bi rezultati provjera dali što vjerniju sliku o znanju učenika. Također valja napomenuti da sve vrste zadataka istodobno imaju i prednosti i nedostatke (Radanović i sur, 2013) koje sastavljači trebaju dobro poznavati kako bi se zadaci u pisanim provjerama znanja primjereno upotrijebili. Pisana provjera za županijsko natjecanje bi trebala biti strukturirana tako da se u njoj nalazi $20 \%$ zadataka kojima se provjerava reprodukcija nastavnih sadržaja, $60 \%$ zadataka kojima se provjerava konceptualno razumijevanje i primjena znanja i 20 \% zadataka kojima se provjerava sposobnost rješavanja problema (Radanović i sur, 2013).

Pisane provjere na županijskom natjecanju iz biologije sastavljene su od niza zadataka objektivnog tipa u kojima je točan odgovor jednoznačno određen i mogu se objektivno procijeniti (Vizek-Vidović i sur, 2003). U pisanim provjerama za natjecanje srednjoškolske populacije učenika nalaze se ovi tipovi zadataka objektivnog tipa: zadaci višestrukog izbora sa samo jednim točnim odgovorom, zadaci višestrukog izbora s dva točna odgovora, zadaci povezivanja, serije zadataka alternativnog tipa, zadaci

Grgurić, I., , Begić, V., Bastić, M., Lukša, Ž., Radanović, I. 2017. Kvaliteta pitanja i uspjeh srednjoškolskih sudionika natjecanja iz biologije u znanju. Educ. biol. 3, 1, 32-56. 
sređivanja u kombinaciji zadataka različitog tipa te zadaci kratkog odgovora kao zadaci produženog odgovora kao zadaci otvorenog tipa.

S ciljem da se poboljša kvaliteta pitanja te dobije uvid u uspješnost srednjoškolske populacije učenika na Županijskom natjecanju iz biologije koje je održano 2015. godine, postavljeni su parcijalni ciljevi ovog istraživanja:

analizirati kvalitativnu strukturu pitanja i povezanost utjecaja elemenata procjene kvalitete pitanja na konačnu kvalitetu pitanja

analizirati povezanost elemenata procjene kvalitete pitanja s uspjehom učenika u njihovu rješavanju

utvrditi utjecaj iskustva nastavnika u pripremi zadataka na uspješnost kvalitativne procjene zadataka.

\section{MATERIJALI I METODE}

Za istraživanje su se koristile pisane provjere sa Županijskog natjecanja iz biologije za učenike od prvog do četvrtog razreda gimnazije održanog 18. ožujka 2015. godine. $20 \%$ najbolje riješenih pisanih provjera po županijama uključivalo je pisane provjere 362 učenika gimnazije. Pisane provjere sa Županijskog natjecanja iz biologije sadrže od 16 do 21 pitanje, ali su često uključena potpitanja kojima učenici mogu ukupno ostvariti 50 bodova. Tako se provjera za prvi razred sastoji od ukupno 33 pitanja, provjera za drugi razred od 43 pitanja, provjera za treći razred od 29 pitanja, a provjera za četvrti razred od 50 pitanja. Potpitanja su analizirana zasebno, ali i kao cjelina u odgovarajućem zadatku, kako bi se dobili što točniji rezultati.

Za analizu pitanja koristila se metoda stručne procjene kvalitete pitanja i analiza odgovora na osnovu klasa riješenosti uz kognitivno kodiranje odgovora na pitanja otvorenog tipa prema Radanović i sur. (2017b). Kod pitanja otvorenog tipa određivana je kognitivna kvaliteta odgovora, zbog toga jer svaki netočan odgovor u suštini nije jednak. Nakon što je provedena analiza odgovora na pitanja otvorenog tipa, utvrđeni su problemi koji se javljaju pri učenju i poučavanju te su u nekim slučajevima određene miskoncepcije vezane uz njega.

Statistička analiza provedena je korištenjem Statistics Toolkit - StatsToDo (Chang, 2014), a korelacije su interpretirane prema Hopkins (2000). Razlike frekvencija pojedinih klasa učenika prema ukupnoj uspješnosti analizirana je $\chi^{2}$ testom. Kruskal-Wallisov test korišten je za analize pri kojima je uspjeh učenika prikazan u obliku klasa riješenosti, a obuhvaćaju raspon riješenosti od 10 \% (Radanović i sur, 2017c). Povezanost varijabli utvrđivana je uz pomoć indeksa korelacije. Pearsonov koeficijent korelacije ( $r$ ) korišten je u slučajevima linearne povezanosti i normalne distribucije pri određivanju povezanosti procijenjene i stvarne težine zadataka te utjecaja elemenata procjene zadataka na njihovu riješenost. Pomoću Spearmanovog koeficijentna korelacije $(\rho)$ utvrđena je povezanost težine pitanja i njene procjene te uspješnosti pri rješavanju provjere i odgovarajuće kognitivne razine pitanja.

Nakon analize provjera za detaljni prikaz odbrana su pitanja koja se po određenim karakteristikama razlikuju od ostalih pitanja: sadrže očekivane miskoncepcije, važna su za propisani plan i program, važna su za život, ostvaruju kritičko mišljenje, riješenost je veća ili manja u odnosu na procijenjenu, distraktora nejednake težine, konceptualnog nerazumijevanja kao posljedice čitanja uvodnog teksta, distraktora opterećenih nazivima, problema pri interpretaciji podataka iz grafičkog prikaza, interdisciplinarnog karaktera pitanja, korištenja manje značajnih informacija pri izradi distraktora, konceptualnog nerazumijevanja, konceptualnog nerazumijevanja čitanja podataka iz grafičkog prikaza.

Grgurić, I., , Begić, V., Bastić, M., Lukša, Ž., Radanović, I. 2017. Kvaliteta pitanja i uspjeh srednjoškolskih sudionika natjecanja iz biologije u znanju. Educ. biol. 3, 1, 32-56. 


\section{REZULTATI}

Određena je kvaliteta pitanja za svaku kategoriju natjecanja u znanju u skladu s razredom srednje škole po elementima važnosti pitanja i utjecaja pitanja na odgovor. Sva su pitanja u rasponu vrijednosti procjene kvalitete pitanja 1.5 do 2.5 te su kvalitetom prihvatljiva, no ni jedno pitanje nije procijenjeno kao loše, ali niti jedno nije procijenjeno kao dobro. Većina pitanja u pisanim provjerama je prihvatljive kvalitete (65\%), pri čemu je $52 \%$ pitanja u rangu srednje vrijednosti procjene iznad 2, ali manje od 2,5. Elementi procijene važnosti pitanja kreću se u rasponu srednje važnosti, najveća zastupljenost pitanja za poticanje prirodoslovne pismenosti je u provjeri za četvrti razred (50\%), dok ja najmanja u provjeri za prvi razred (18 \%). Prema vrsti pitanja (tablica 1) u klasi prihvatljivih pitanja najbolje su procijenjena pitanja kratkog odgovora s najmanjim odstupanjem u kvaliteti između razreda, dok su kvalitetom bila najslabija pitanja višestrukog odabira s dva točna odgovora koja su i najmanje procijenjene važnosti za poticanje biološke pismenosti učenika. U provjerama su u istom zadatku pripremljena pitanja različitog tipa pa su takvi zadaci pri ukupnoj analizi svrstani u kategoriju višestruke kombinacije.

Tablica 1 Karakteristike pitanja prema kategorijama procjene kvalitete i riješenosti

\begin{tabular}{|c|c|c|c|c|c|c|c|}
\hline \multirow{2}{*}{ VRSTA ZADATKA } & \multirow{2}{*}{ OPISNICA } & \multicolumn{4}{|c|}{ RAZRED } & \multirow{2}{*}{$\begin{array}{c}\text { srednja } \\
\text { vrijednost }\end{array}$} & \multirow{2}{*}{ SD } \\
\hline & & 1. & 2. & 3. & 4. & & \\
\hline \multirow{4}{*}{$\begin{array}{l}\text { višestruki izbor (5) } \\
\text { - jedan točan odgovor }\end{array}$} & kvaliteta pitanja & 1,82 & 2,07 & 2,02 & 1,97 & 1,97 & 0,11 \\
\hline & važnost pitanja & 1,69 & 1,91 & 1,84 & 1,71 & 1,79 & 0,11 \\
\hline & utjecaj pitanja na odgovor & 1,95 & 2,23 & 2,20 & 2,22 & 2,15 & 0,13 \\
\hline & riješenost (\%) & 55,24 & 60,50 & 73,50 & 19,00 & 52,06 & 23,34 \\
\hline \multirow{4}{*}{$\begin{array}{l}\text { višestruki izbor (5) } \\
\text { - dva točna odgovora }\end{array}$} & kvaliteta pitanja & 1,84 & 1,92 & 1,86 & & 1,87 & 0,04 \\
\hline & važnost pitanja & 1,67 & 1,69 & 1,53 & & 1,63 & 0,09 \\
\hline & utjecaj pitanja na odgovor & 2,01 & 2,16 & 2,20 & & 2,12 & 0,10 \\
\hline & riješenost (\%) & 53,61 & 55,50 & 52,67 & & 53,93 & 1,44 \\
\hline \multirow{4}{*}{$\begin{array}{l}\text { serija } \\
\text { alternativnog izbora }\end{array}$} & kvaliteta pitanja & 1,83 & & 1,93 & 2,14 & 1,96 & 0,16 \\
\hline & važnost pitanja & 1,65 & & 1,76 & 2,18 & 1,86 & 0,28 \\
\hline & utjecaj pitanja na odgovor & 2,00 & & 2,10 & 2,10 & 2,07 & 0,06 \\
\hline & riješenost (\%) & 8,15 & & 64,50 & 20,33 & 30,99 & 29,65 \\
\hline \multirow{4}{*}{ povezivanje } & kvaliteta pitanja & 1,88 & 1,84 & 1,86 & & 1,86 & 0,02 \\
\hline & važnost pitanja & 1,65 & 1,73 & 1,58 & & 1,65 & 0,08 \\
\hline & utjecaj pitanja na odgovor & 2,10 & 1,95 & 2,14 & & 2,06 & 0,10 \\
\hline & riješenost (\%)t & 61,11 & 1,00 & 47,00 & & 36,37 & 31,43 \\
\hline \multirow{4}{*}{ višestruke kombinacije } & kvaliteta pitanja & & 2,03 & 2,06 & 1,99 & 2,03 & 0,04 \\
\hline & važnost pitanja & & 1,89 & 1,91 & 1,73 & 1,84 & 0,10 \\
\hline & utjecaj pitanja na odgovor & & 2,18 & 2,21 & 2,25 & 2,21 & 0,04 \\
\hline & riješenost (\%) & & 20,00 & 60,00 & 4,00 & 28,00 & 28,84 \\
\hline \multirow{4}{*}{ kratki odgovor } & kvaliteta pitanja & 2,10 & 2,03 & 2,08 & 2,21 & 2,10 & 0,08 \\
\hline & važnost pitanja & 2,05 & 2,13 & 2,03 & 2,25 & 2,11 & 0,10 \\
\hline & utjecaj pitanja na odgovor & 2,15 & 1,93 & 2,14 & 2,18 & 2,10 & 0,12 \\
\hline & riješenost (\%) & 11,11 & 26,67 & 32,50 & 32,67 & 25,74 & 10,14 \\
\hline \multirow{4}{*}{ UKUPNO } & kvaliteta pitanja & 1,89 & 1,98 & 1,97 & 2,08 & 1,98 & 0,08 \\
\hline & važnost pitanja & 1,74 & 1,87 & 1,77 & 1,97 & 1,84 & 0,10 \\
\hline & utjecaj pitanja na odgovor & 2,04 & 2,09 & 2,16 & 2,19 & 2,12 & 0,07 \\
\hline & riješenost (\%) & 37,84 & 32,73 & 55,03 & 19,00 & 36,15 & 14,89 \\
\hline
\end{tabular}

Pitanja koja su nevažna za biološku pismenost najviše su zastupljena u prvom (9\%), a najmanje u drugom (2\%) razredu. Temeljem analize utjecaja pitanja na odgovor učenika može se uočiti da svako pitanje ima bar nekakav utjecaj na odgovor učenika, odnosno procijenjeno je prema srednjoj vrijednosti iznad 1,65. Pitanja srednje utječu na odgovor učenika, a najveći utjecaj je zabilježen kod pitanja višestruke kombinacije u provjeri za 4. razred, dok su pitanja za 1. razred imala najmanji utjecaj na učenike pri njihovu rješavanju. Srednja riješenost pisanih provjera od 36 \% nešto je niža od uobičajene srednje riješenosti pisanih provjera iz biologije od 40 \% na razini RH (Garašić i sur. 2013).

Pitanja koja su zastupljena u pisanim provjerama većinom su srednje teška (71 \%), zatim teška (21 \%), a prisutna su i lagana pitanja (8 \%). Najviše teških pitanja nalazi se u pisanoj provjeri za treći (24 \%) i prvi

Grgurić, I., , Begić, V., Bastić, M., Lukša, Ž., Radanović, I. 2017. Kvaliteta pitanja i uspjeh srednjoškolskih sudionika natjecanja iz biologije u znanju. Educ. biol. 3, 1, 32-56. 
(24 \%) razred, a najmanje u provjeri za četvrti razred (14 \%). Pitanja srednje težine najzastupljenija su u provjeri za četvrti (84 \%), a provjera prvih razreda sadrži najviše laganih pitanja (24\%). U pisanim provjerama je najviše zastupljena druga kognitivna razina (61 \%), zatim prva razina (30\%), a najmanje treća kognitivna razina (9 \%). Najveći broj pitanja koja provjeravaju prvu kognitivnu razinu nalazi se u pisanoj provjeri za treći (48 \%), a najviše pitanja koja provjeravaju primjenu znanja nalazi se u provjeri za četvrti (74 \%). Pitanja koja provjeravaju treću kognitivnu razinu najzastupljenija se u provjeri za četvrti razred (14\%), dok se u pisanoj provjeri za treći razred ne nalazi niti jedno pitanje koje provjerava sposobnost rješavanja problema.

Prema tipu pitanja može se uočiti reproduktivni karakter pitanja višestrukog izbora i konzistentnija provjera konceptualnog razumijevanja pitanjima kratkog odgovora (slika 1). Prisutna je glavna negativna korelacija ostvarene težine pitanja prema indeksu težine u odnosu na procijenjenu težinu od strane nastavnika $(\rho=-0,69)$. Nastavnici najmanje griješe u procjeni zadataka višestrukog izbora $s$ jednim točnim odgovorom (razlika proporcija $=-0,06$ ) i u procjeni težine pitanja kratkog odgovora (razlika proporcija $=-0,16)$.

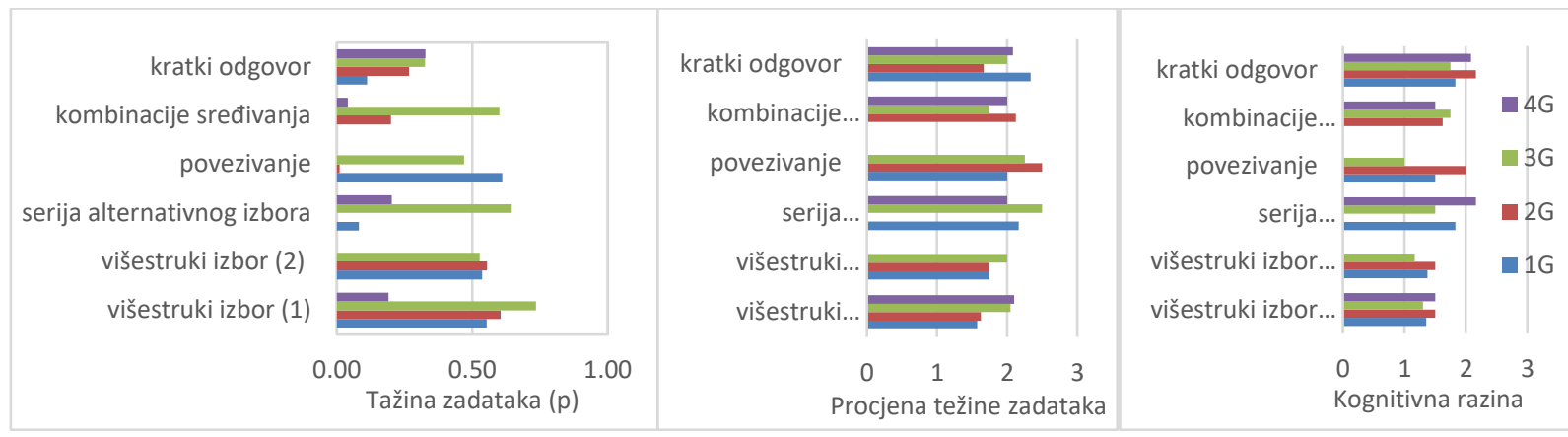

Slika 1 Aritmetičke sredine riješenosti zadataka u provjerama za pojedini razred prema tipu zadatka

U svrhu analize povezanosti utjecaja elemenata procjene kvalitete pitanja na konačnu kvalitetu pitanja iz svake je provjere izdvojeno po deset najbolje, odnosno najslabije procijenjenih pitanja. Izdvojena pitanja, izuzev jednog pitanja, kvalitetom su procijenjena ispod vrijednosti 2 , što upućuje da je veliki broj pitanja u svim provjerama iako prihvatljive još uvijek nedovoljno dobre kvalitete, osobito jer je riječ o pitanjima koja su namijenjena za natjecanja učenika u znanju.

Na kvalitetu najslabije riješenih pitanja veliki utjecaj imaju u podjednakoj povezanosti podataka kategorije utjecaja na rješavanje pitanja $(\rho=0,56)$ kao i važnost pitanja za poticanje prirodoslovne pismenosti $(\rho=0,52)$ pri čemu najveći utjecaj ima važnost pitanja za struku $(\rho=0,58)$. Utvrđena je vrlo visoka povezanost kategorije važnosti pitanja za poticanje razvoja prirodoslovne pismenosti kod ovih pitanja s uočenim poticanjem kritičkog razmišljanja $(\rho=0,70)$ te velika povezanost $s$ važnosti pitanja za propisani nastavni program $(\rho=0,66)$ i važnosti pitanja za struku $(\rho=0,59)$ kao i kognitivne razine pitanja $(\rho=0,56)$. Takav rezultat ukazuje da su upravo tim komponentama autori pitanja posvetili najveću pažnju. Autori su također prema korelativnoj povezanosti elemenata procjene na utjecaj pitanja pri njegovu rješavanju veliku pažnju posvetili oblikovanju pitanja $(\rho=0,58)$ i njegovoj razumljivosti, a vrlo im je važno bilo da pri rješavanju zadataka učenici ne koriste samo sposobnost logičkog razmišljanja $(\rho=0,71)$ već da primjene svoje znanje.

Analizirana pitanja najbolje kvalitete pokazuju vrlo veliku povezanost s kategorijom važnosti pitanja za poticanje prirodoslovne pismenosti kod učenika $(\rho=-0,60)$ i svim njenim elementima procjene izuzev

Grgurić, I., , Begić, V., Bastić, M., Lukša, Ž., Radanović, I. 2017. Kvaliteta pitanja i uspjeh srednjoškolskih sudionika natjecanja iz biologije u znanju. Educ. biol. 3, 1, 32-56. 
srednje povezanosti s poticanjem kritičkog mišljenja $(\rho=0,47)$ što ukazuje da najkvalitetniji zadaci ipak još nedovoljno potiču učenike u razmišljanju i konceptualnom povezivanju. Izostanak povezanosti kvalitete pitanja s kategorijom utjecaja pitanja na odgovor učenika ukazuje da je neophodno pri sastavljanju pitanja za natjecanje još veću pažnju usmjeriti na oblikovanje i razumljivost pitanja. $S$ obzirom da se radi o natjecanju učenika prihvatljiv je zabilježen manji utjecaj $(\rho=-0,15)$ dodatnog učenja učenika za uspješno rješavanje pitanja, pri čemu treba voditi brigu da se dodatno učenje usmjerava prema primjeni znanja i proširivanju razumijevanja, a ne na upamćivanju nekog podatka koji su učenici trebali pročitati. Pri sastavljanju najkvalitetnijih pitanja u provjerama autori su veliku pažnju poklonili svim elementima poticanja razvoja prirodoslovne pismenosti kod učenika $(\rho=0,63-0,73)$. Utvrđena umjerena povezanost težine pitanja s ovom komponentom $(\rho=0,41)$ ukazuje da autori nastoje da pitanja za poticaj razvoja prirodoslovne pismenosti ne budu preteška učenicima za rješavanje. Autori nastoje da pitanja budu primjereno oblikovana $(\rho=0,73)$ te da ih učenici ne rješavaju samo uz pomoć logičkog razmišljanja $(\rho=0,60)$, pri čemu su najbolja pitanja srednje razumljiva učenicima, a čemu bi se ubuduće trebalo pokloniti više pažnje. Također autori pitanja trebaju ubuduće nastojati da se kod pitanja koja su tehnički dotjerana te time nemaju utjecaj na rješavanje, više pažnje pokloni usmjeravanju na poticanje prirodoslovne pismenost, a posebno kritičkog mišljenja, na što ukazuje negativna povezanost ove kategorije $(\rho=-0,60)$ i njenog bitnog elementa $(\rho=-0,59)$ s kategorijom utjecaja pitanja na odgovor učenika.

U odnosu na postignutu riješenost zadataka utvrđena je mala povezanost pitanja slabije kvalitete ( $\rho=$ $0,15)$ i srednja povezanost kvalitetnijih pitanja $(\rho=0,37)$ s procjenom riješenosti, što je još jedna potvrda o prihvatljivoj kvaliteti zadataka. Težina pitanja $(\rho=-0,37$ i $-0,58)$ i kognitivna razina $(\rho=-0,40$ i $-0,43)$ srednje su obrnuto proporcionalno povezane s ostvarenom riješenosti što je i za očekivati kako bi se provjerom moglo dobro izlučiti najuspješnije učenike. Pritom bolja povezanost kod kvalitetnijih pitanja potvrđuje važnost pripreme pitanja uz uvažavanje elemenata procjene kvalitete, a posebno primjene kritičkog razmišljanja u zadacima provjere konceptualnog razumijevanja i sposobnosti rješavanja problema.

Analiza je provedena na 362 pisane provjere sa Županijskog natjecanja iz biologije 2015. godine (slika 2).

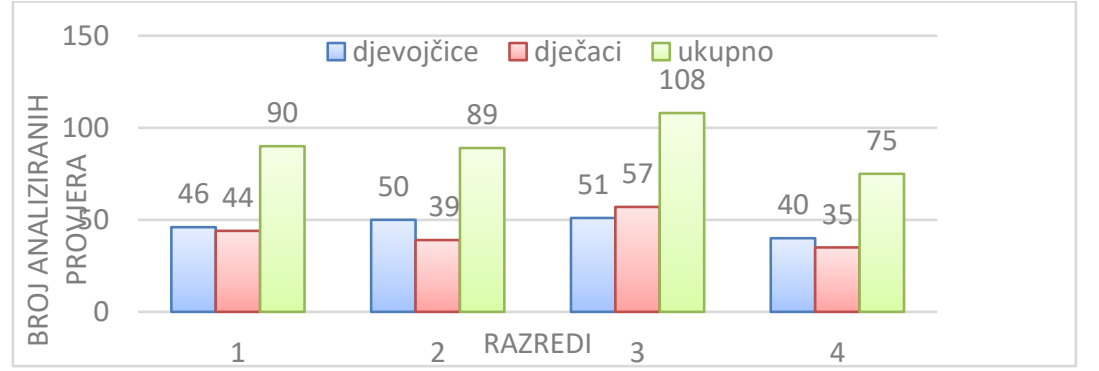

Slika 2 Zastupljenost učenika po razredu i spolu u kategoriji 20 \% najuspješnijih sudionika natjecanja u znaju

Najveći broj učenika na natjecanju zastupljen je u trećem razredu (30\%), najmanji broj u četvrtom razredu (21\%), dok je zastupljenost učenika u prvom (25\%) i drugom (24\%) razredu podjednaka (slika 2). Budući da se u trećem razredu veći dio školske godine obrađuju nastavni sadržaji vezani za građu i funkcije ljudskoga tijela, a ujedno je to najzanimljivije i najbliže učenicima, ne iznenađuje podatak da se upravo iz trećeg razreda prijavilo najviše učenika za natjecanje. $S$ druge strane najmanja zastupljenost učenika bila je u četvrtom razredu. Pretpostavka za tako malu brojnost učenika u četvrtom razredu je priprema za maturu i nastavak školovanja. Nastavni sadržaji koji se obrađuju u drugom razredu

Grgurić, I., , Begić, V., Bastić, M., Lukša, Ž., Radanović, I. 2017. Kvaliteta pitanja i uspjeh srednjoškolskih sudionika natjecanja iz biologije u znanju. Educ. biol. 3, 1, 32-56. 
(zoologija i botanika) opterećeni su brojnim informacijama i pojmovima koje treba memorirati što je vjerojatni razlog malog broja prijavljenih učenika iz drugog razreda na natjecanje. Za natjecanje u prvom razredu vjerojatno su se prijavili oni učenici koji su sudjelovali na natjecanju iz biologije i u osnovnoj školi. Zastupljenost dječaka i djevojčica u svim razredima je podjednaka, ali djevojčice ipak prevladavaju. To se najbolje vidi u drugom razredu, gdje je zastupljenost djevojčica $56 \%$, a dječaka $43 \%$. Iznimka je treći razred gdje je zastupljenost dječaka $53 \%$, a djevojčica $47 \%$ (slika 2).

Prema uspješnosti učenika rezultati su prikazani po klasama riješenosti pitanja. Broj klasa je u skladu sa zahtjevnošću provjere i karakteristikama pitanja, a učenici koji ostvaruju $20 \%$ najboljih rezultata unutar svojih županija, raspoređeni su u klase više od 30 \% riješenosti provjere (slika 3). Analizom riješenosti i raspodjele postignuća učenika uočava se da je provjera u prvom razredu bila najteža, jer obiluje teškim reproduktivnim zadacima, ali samo za $2 \%$ teža od provjere za četvrti razred koja je večim dijelom sastavljena od srednje teških zadataka koji su provjeravali primjenu znanja i razumijevanje. Provjera u drugom razredu bila je prelagana za sudionike natjecanja čije su zadaće dostavljene državnom povjerenstvu (slika 3).

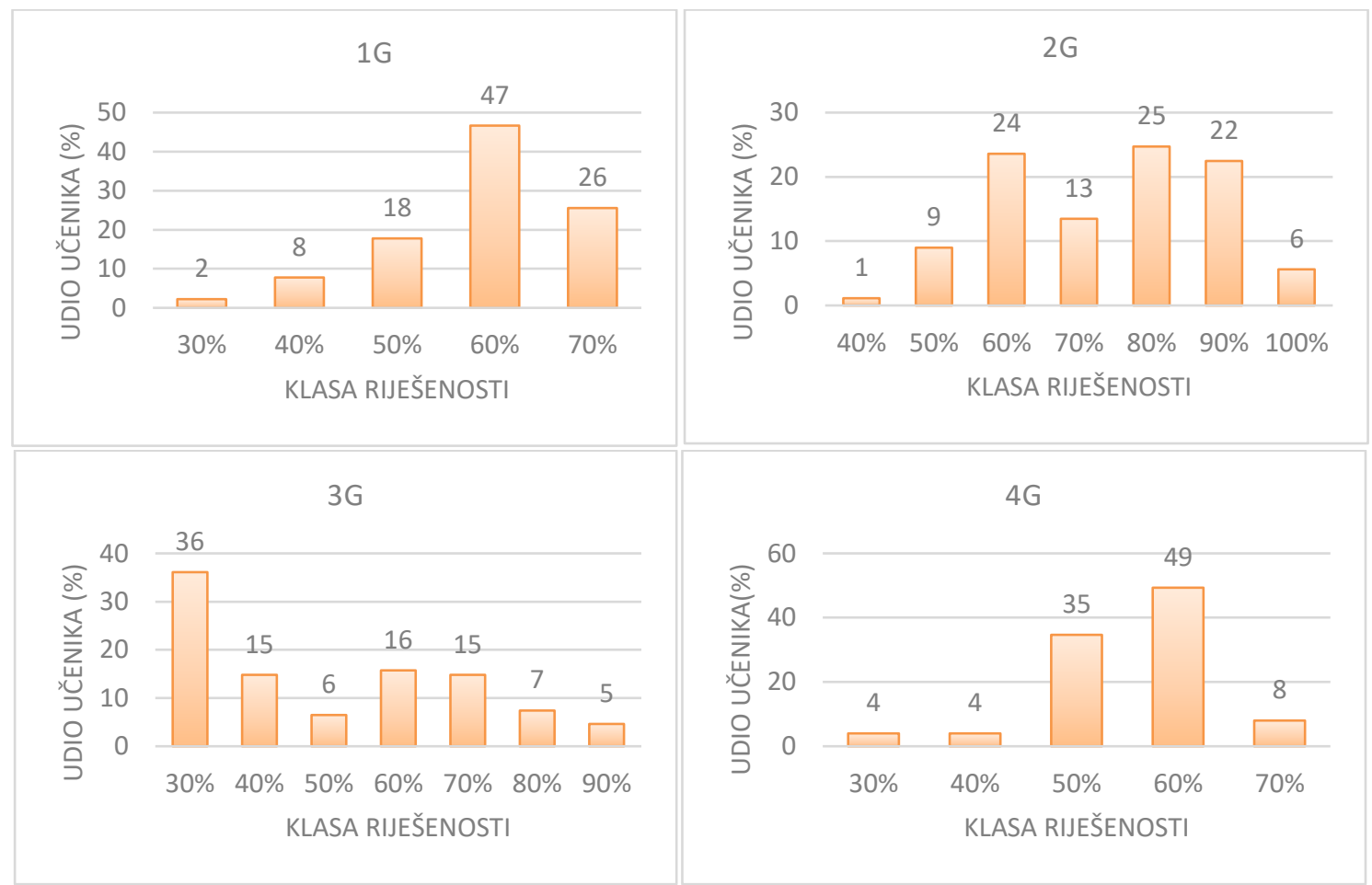

Slika 3 Raspodjela učenika prema klasama uspješnosti u odnosu na provjeru za odgovarajući razred sudionika natjecanja (1G 1. razred. $2 \mathrm{G}-2$. razred. $3 \mathrm{G}-3$. razred. $4 \mathrm{G}-4$. razred)

Procjena riješenosti pitanja za 1. razred gimnazije kreće se u rasponu od $30 \%$ do $80 \%$ i pokazuje veliku povezanost $(\rho=0,53)$ sa stvarnom riješenosti $(M=41,75 \% \pm 31,08)$. Najviše pitanja je I. kognitivne razine $(M=1,52 \pm 0,51)$, težina pitanja je srednja $(M=1,82 \pm 0,63)$, a kvaliteta prihvatljiva $(M=1,93 \pm 0,16)$. Najniže procijenjenu kvalitetu ima prvo pitanje $(1,65)$, a najveću potpitanje 18c (2,36). Pitanje 13 je zanimljivo jer se ukupna procjena riješenosti (30 \%) podudara s procijenjenom riješenosti potpitanja $(13 a=30 \%, 13 b=30 \%)$. Procjena riješenosti pitanja za 2 . razred kreće se u rasponu od $30 \%$ do $70 \%$ te pokazuje srednju povezanost $(\rho=0,42)$ sa stvarnom riješenosti $(M=56,83 \% \pm 23,75)$. Kvaliteta pitanja je prihvatljiva, bez značajnih razlika između pitanja ( $M=2,00 \pm 0,17)$. Za većinu pitanja je važno razumijevanje da bi se postigla što bolja riješenost, jer najviše pitanja je II. kognitivnu razine $(M=1,67 \pm$

Grgurić, I., , Begić, V., Bastić, M., Lukša, Ž., Radanović, I. 2017. Kvaliteta pitanja i uspjeh srednjoškolskih sudionika natjecanja iz biologije u znanju. Educ. biol. 3, 1, 32-56. 
$0,48)$, a prosječna težina pitanja je srednja ( $M=1,83 \pm 0,42$ ). Najmanje procijenjenu kvalitetu ima potpitanje $15 b(1,61)$, a najveću potpitanje $9 c(2,40)$. Procjena točnosti pitanja za 3 . razred kreće se u rasponu od $40 \%$ do $70 \%$ uz malu povezanost $(\rho=0,27)$ sa stvarnom riješenosti $(M=59,28 \% \pm 28,84)$. Pitanja 9. $(1,69)$ i $21 \mathrm{~b}(1,76)$ ističu se najmanjim vrijednostima kvalitete pitanja, a potpitanje $21 \mathrm{c}$ ima procijenjenu najbolju kvalitetu $(2,40)$. Najviše pitanja je I. kognitivne razine $(M=1,33 \pm 0,35)$, a težina pitanja je srednja $(M=1,97 \pm 0,45)$. Procjena riješenosti pitanja 4 . razreda kreće se u rasponu od $40 \%$ do $70 \%$ i pokazuje malu povezanost $(\rho=0,13)$ sa stvarnom riješenosti ( $M=36,64 \% \pm 20,67)$. Pitanja 9 , 10 i 14 najviše potiču učenike na primjenu kritičkog mišljenja $(2,4)$. Najveću procijenjenu kvalitetu ima potpitanje $16 \mathrm{VIII}(2,33)$. Pitanja su većim dijelom II. kognitivne razine $(\mathrm{M}=1,80 \pm 0,44)$ i srednje težine $(\mathrm{M}=2,03 \pm 0,31)$.

\section{Analiza odabranih pitanja}

Nakon analize pisanih provjera odabrana su pitanja koja se po određenim elementima razlikuju od ostalih pitanja. Ukupno je odabrano dvanaest pitanja, ali je komentirano samo sedam pitanja koja su smisleno provjeravala polazišne koncepte (tablica 2), kako bi se na osnovu njihove analize uočile mogućnosti za poboljšanja.

Tablica 2 Biološki koncepti, ishodi prema katalogu državne mature i teme u Nastavnom planu i programu koje provjeravaju odabrana pitanja za analizu u pisanim provjerama sa županijskog natjecanja iz biologije 2015. godine

\begin{tabular}{|c|c|c|c|}
\hline PITANJE & KONCEPT & ISHOD UČENJA & TEMA U PIP- $U$ \\
\hline$N B 1-2$ & $\begin{array}{l}\text { Ustrojstvo bioloških subjekata bez } \\
\text { stanične organizacije }\end{array}$ & Objasniti građu i podjelu virusa & Virusi - čestice ili stanice? \\
\hline NB2-6 & Životni ciklus organizma & $\begin{array}{l}\text { Usporediti životne cikluse životinjskih } \\
\text { organizama }\end{array}$ & $\begin{array}{l}\text { Carstvo protoktista - kremenjašice } \\
\text { (Diatomeae) }\end{array}$ \\
\hline$N B 2-13 b$ & Znanstvena metodologija & $\begin{array}{l}\text { Analizirati numerički i grafički prikazane } \\
\text { rezultate istraživanja }\end{array}$ & Važnost bakterija za čovjeka i prirodu \\
\hline NB3-20b & Znanstvena metodologija & $\begin{array}{l}\text { Analizirati podatak na temelju uvodnog teksta i } \\
\text { izračuna }\end{array}$ & Krv i krvne stanice \\
\hline$N B 4-1$ & $\begin{array}{l}\text { Nasljeđivanje na razini } \\
\text { organizama }\end{array}$ & $\begin{array}{l}\text { Povezati stalnost broja, građe i oblika } \\
\text { kromosoma (gena) s definicijom vrste kao } \\
\text { reproduktivno izolirane skupine organizama }\end{array}$ & Genetika - gen, DNA i kromosomi \\
\hline NB4-3 & $\begin{array}{l}\text { Nasljeđivanje na razini } \\
\text { organizama }\end{array}$ & $\begin{array}{l}\text { Primijeniti zakone nasljeđivanja na konkretnim } \\
\text { zadatcima uz objašnjenja } \\
\text { Mendelovih zakona }\end{array}$ & Genetika - nasljeđivanje po Mednelu \\
\hline NB4-12b & Znanstvena metodologija & $\begin{array}{l}\text { Analizirati numerički i grafički prikazane } \\
\text { rezultate istraživanja }\end{array}$ & Regulacija aktivnosti gena \\
\hline
\end{tabular}

Prema konceptualnoj podjeli najviše komentiranih pitanja pripada u koncept Znanstvena metodologija, koji je, iako izuzetno važan, do sada zanemaren koncept u razvoju biološke pismenosti učenika. Pitanje za prvi razred vezano uz ovaj koncept bilo je prilično usmjereno na reproduktivno znanje pa je između ostalog traženo od učenika da navedu definiciju nezavisne varijable, a za provjeru tog koncepta iznimno je važno provjeriti konceptualno razumijevanje ili barem primjenu znanja. Pitanja su uglavnom vezana uz čitanje podataka iz grafičkih prikaza te rješavanje problema temeljem analize teksta. To bi se u budućnosti trebalo promijeniti prema rješavanju problema uz dodatne informacije u uvodnom tekstu zadatka, a koje su neophodne za nadopunu osnovnog znanja usvojenog tijekom učenja u školi. Ograničavajući čimbenik u pripremi zadataka je i usmjerenost kataloga natjecanja na Nastavni program koji je izrazito sadržajno orijentiran (tablica 2). Daljnjom analizom napravljena je procjena kvalitete odabranih pitanja (tablica 3), pri čemu se većom kvalitetom izdvajaju pitanja 4-3 i 4-12b za 4. razred.

Tablica 3 Opisnice procijene kvalitete pitanja i njihova riješenost za odabrana pitanja u pisanim provjerama sa županijskog natjecanja iz biologije za učenike srednjih škola 2015. godine

Grgurić, I., , Begić, V., Bastić, M., Lukša, Ž., Radanović, I. 2017. Kvaliteta pitanja i uspjeh srednjoškolskih sudionika natjecanja iz biologije u znanju. Educ. biol. 3, 1, 32-56. 


\begin{tabular}{|c|c|c|c|c|c|c|c|}
\hline PITANJE & $\begin{array}{c}\text { KOGNITIVNA } \\
\text { RAZINA }\end{array}$ & $\begin{array}{l}\text { PROCJENA } \\
\text { TEŽINE }\end{array}$ & $\begin{array}{c}\text { PROCJENA } \\
\text { RIJEŠENOSTI (\%) }\end{array}$ & RIJEŠENOST (\%) & $\begin{array}{l}\text { Važnost } \\
\text { pitanja }\end{array}$ & $\begin{array}{c}\text { Utjecaj } \\
\text { pitanja na } \\
\text { odgovor }\end{array}$ & $\begin{array}{c}\text { Kvaliteta } \\
\text { pitanja }\end{array}$ \\
\hline NB1-2 & II & 2 & 40 & 8 & 1,50 & 2,10 & 1,80 \\
\hline$N B 2-6$ & 1 & 1 & 30 & 51 & 1,50 & 1,80 & 1,80 \\
\hline$N B 2-13 b$ & II & 2 & 30 & 68 & 2,48 & 2,10 & 2,10 \\
\hline$N B 3-20 b$ & II & 2 & 40 & 15 & 2,25 & 1,80 & 1,80 \\
\hline$N B 4-1$ & 1 & 2 & 50 & 16 & 1,80 & 2,40 & 1,80 \\
\hline NB4-3 & II & 3 & 40 & 4 & 1,95 & 2,10 & 2,70 \\
\hline$N B 4-12 b$ & II & 2 & 50 & 44 & 2,25 & 1,80 & 2,70 \\
\hline
\end{tabular}

Iz provjere za 1. razred izabrano je pitanje NB1-2 zbog manje riješenosti od one procijenjene.

\section{PITANJE NB1-2}

Koji od navedenih virusa ima sposobnost ugradnje vlastite DNA u jezgru živčanih stanica?
a) HIV
b) FAG
c) $V M D$
d) retrovirus
e) virus herpesa $(T)$

Nastavni sadržaj se obrađuje pod cjelinom Stanica - otkriće, raznolikost i građa (virusi). Procjena riješenosti je $40 \%$, ali srednje teško pitanje koje traži primjenu znanja uspješno je riješilo samo 8 \% učenika (tablica 3). Od svih distraktora najbolji je bio distraktor $d$ ) koji je zaokružilo 33 \% učenika, a samo $1 \%$ učenika nije odabralo odgovor na pitanje. Odgovor e) koji je ujedno i točan zaokružilo je 7,8 \% učenika (slika 4).

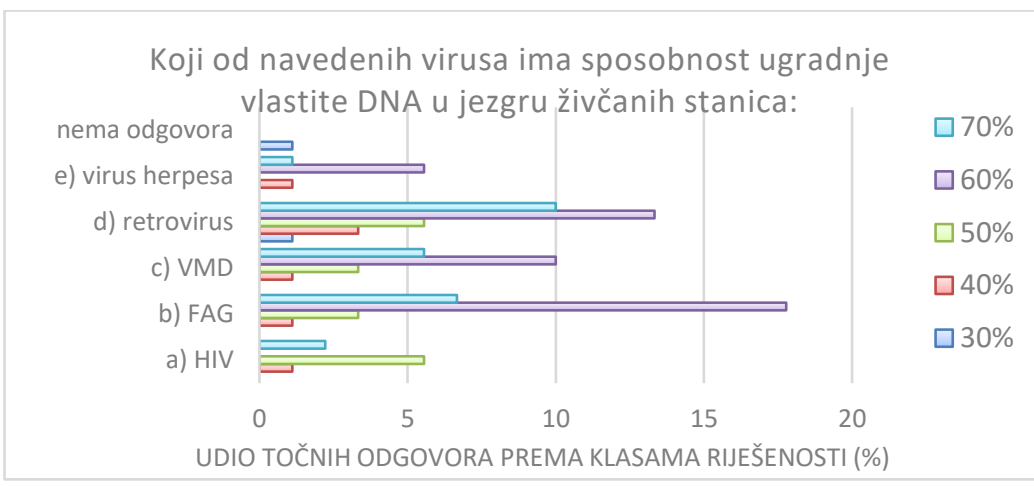

Slika 4 Analiza odgovora uz pitanje NB1-2 za 1. razred

Pitanje je važno za struku, ali se do odgovora moglo doći eliminacijom ponuđenih odgovora, a uzrok maloj riješenosti može biti i korištenje kratica u nazivu virusa. Učenici šeste klase dali su najviše netočnih odgovora, a slijede ih učenici iz sedme i pete klase što ukazuje da pitanje nije dobro jer na njega točno ne odgovaraju najuspješniji učenici. S obzirom na odabir točnog ili netočnog odgovora nije utvrđena statistički značajna razlika između učenika različitih klasa uspješnosti $\left(\chi^{2}=2,137 ; p=0,711 ; d f=4\right)$, što upućuje na probleme vezane uz rješavanje ovog pitanja. Na probleme pri zapamćivanju ili pri učenju ukazuju veliki postoci odabira distraktora b), c) $i$ d) u svim klasama riješenosti (slika 4). Moguće objašnjenje je i eventualni propust pri poučavanju, odnosno da se virus herpesa uglavnom veže na najčešći vidljivi oblik, dok se zanemaruju drugi oblici ovog virusa koji mogu imati teže posljedice za zdravlje. Moguće je da je pitanje tako loše riješeno jer se točan odgovor jako ističe pa su učenici mislili da je u pitanju skrivena zamka, a takva pitanja svakako ne trebaju biti dio pisanih provjera, jer ne prikazuju stvarno znanje učenika. Pitanja NB2-6 i NB2-13b izdvojena su iz provjere za 2. razred zbog bolje postotne riješenosti od procijenjene. Pitanje NB2-6 također je izdvojeno zbog distraktora nejednake 
težine što smanjuje kvalitetu pitanja. Pitanje NB2-13b izdvojeno je i zbog konceptualnog nerazumijevanja kao posljedice čitanja uvodnog teksta, distraktora opterećenih nazivima i problema pri interpretaciji podataka iz loše predstavljenog grafičkog prikaza.

\section{PITANJE NB2-6}

Zbog čega je nakon nespolnog razmnožavanja kremenjašica neophodno spolno razmnožavanje?

a) Stanice nastale diobom nadoknade samo epiteku.

b) Stanice nastale diobom nadoknade samo hipoteku. (T)

c) Stanice nastale diobom ne nadoknađuju ljušturice.

d) Dio stanica nastalih diobom postaje sve veći.

e) Iz zigote se razvije stanica početne veličine. (T)

Teško pitanje višestrukog izbora $s$ dva točna odgovora provjerava primjenu znanja vezanog za kremenjašice. Na pitanje je uspješno odgovorilo $49 \%$ učenika, a procjena je bila $30 \%$. Cjelina pod kojom se obrađuje nastavni sadržaj je Carstvo protoktista - kremenjašice (Daitomeae). Pitanje je važno za struku, a na odgovor učenika najviše utječe razumijevanje pitanja i ponuđenih odgovora te dodatno učenje, odnosno podrška nastavnika pri poučavanju.

Od distraktora najbolji je distraktor $a$ ) koji je zaokružilo $14 \%$ učenika. Zabrinjava činjenica da je distraktor c) zaokružilo $9 \%$ učenika i to pokazuje da ti učenici ne razumiju princip na kojem se temelji razmnožavanje kremenjašica. Točan odgovor e) zaokružilo je najviše učenika, njih $45 \%$ s obzirom da je u odgovoru korišten naziv vezan za spolno razmnožavanje (zigota). Odgovor $b$ ) zaokružilo je $26 \%$ učenika i to su učenici koji uspješno reproduciraju naučene nastavne sadržaje. Težina pitanja leži u logičkom zaključivanju koji dio ljušturice kremenjašica se nadoknađuje diobom. Učenici trebaju znati da je ljušturica izgrađena od dva dijela koja se slažu na principu „kutija - poklopac“. Ovo pitanje je izdvojeno jer je dobar primjer na kojem se može pokazati kako nekvalitetni ponuđeni distraktori mogu utjecati na uspješnost rješavanja pitanja. Nekvaliteni distrakotri sugeriraju na točan odgovor pa tako utječu na uspješnost rješavanja, odnosno postotak riješenosti ne odgovara stvarnom znanju učenika. I najuspješniji učenici nisu bili sigurni u nazivima epiteka i hipoteka (slika 5), a zbunio ih je i besmisleni distraktor ponuđen pod c).

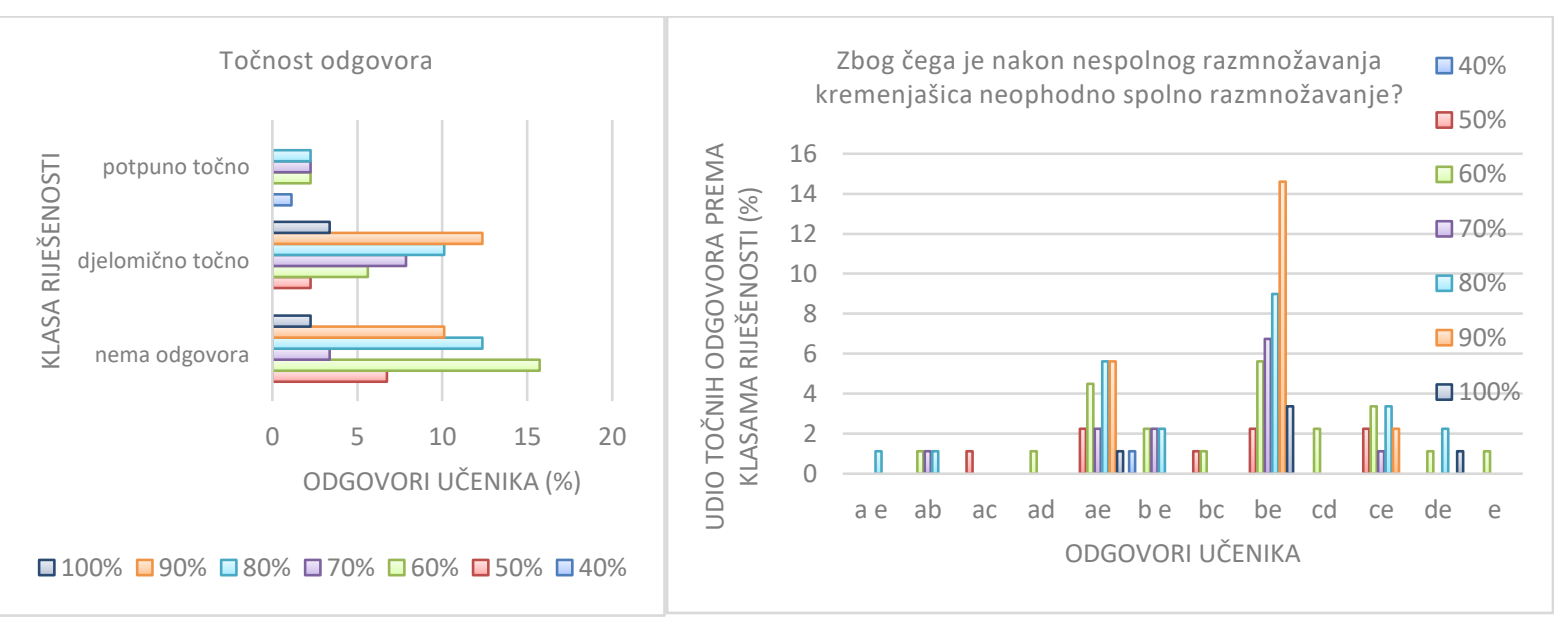

Slika 5 Analiza odgovora i točnosti pitanja NB2-6 za 2. razred

Uz točnost odgovora prema klasama nije utvrđena statistički značajna razlika $\left(\chi^{2}=7,580 ; p=0,270 ; d f=6\right)$ što potvrđuje da na pitanje pogrešno odgovaraju učenici u svim klasama u podjednakom omjeru. Zanimljivo je da učenici najslabije klase uspješnosti koji postižu od $31 \%$ do $40 \%$ bodova na ukupnoj

Grgurić, I., , Begić, V., Bastić, M., Lukša, Ž., Radanović, I. 2017. Kvaliteta pitanja i uspjeh srednjoškolskih sudionika natjecanja iz biologije u znanju. Educ. biol. 3, 1, 32-56. 
provjeri daju točan odgovor na ovo pitanje te se time potvrđuje da ovaj zadatak ne odjeljuje uspješne od neuspješnih učenika te da uz njegovo rješavanje postoji problem.

Da su distraktori, ali i jedan od točnih odgovora bili bolje koncipirani te da je uz pitanje ponuđena odgovarajuće označena slika i uz izostanak provjere naziva epiteka i hipoteka, pitanje bi dobilo na kvaliteti.

\section{NB2-13b}

Radi prevencije razvoja toksičnih plijesni na suhomesnatim proizvodima znanstvenici su istraživali učinak bakterije mliječne kiseline Lactobacillus plantarum na rast plijesni Aspergillus ochraceus (izolirane iz domaćeg slavonskog kulena). Istraživanje rasta ove plijesni provedeno je na tekućim hranjivim podlogama. Kultura istraživane plijesni nacijepljena je na hranjivu podlogu 1 (glukozni agar), a na hranjivu podlogu 2 uz plijesan dodane su bakterijske stanice Lactobacillus plantarum. Obje podloge inkubirane su tijekom 28 dana na $28^{\circ} \mathrm{C}$. Dijagram prikazuje odnose biomasa čiste kulture plijesni i miješane kulture plijesni i mliječne bakterije.

b) Zašto brojnost (biomasa) plijesni na hranjivoj podlozi 1 opada s vremenom?

Očekivani odgovor: Brojnost plijesni opada s vremenom zbog smanjenja (potrošnje) hranjivih tvari u podlozi.

Srednje teško pitanje otvorenog tipa NB2-13b na kojem su učenici trebali prikazati razumijevanje svojim riječima u kratkom odgovoru, bolje je i veće je važnosti (tablica 3). U kategoriji važnosti pitanja za poticanje prirodoslovne pismenosti pitanje je važno u svim segmentima, a na odgovor učenika jedino utječe mogućnost odgovora na osnovu logičkog razmišljanja. Pitanja potaknuta sličnim idejama većinom bi trebala biti zastupljena u pisanim provjerama, jer potiču učenike na primjenu kritičkog mišljenja uz prikaz konceptualnog razumijevanja što je iskazano u ostalim potpitanjima ovog zadatka, a u kojima se traži učenike da objasne djelovanje bakterija na rast plijesni te razloge manjeg kvarenja mesnih prerađevina primjenom rezultata ovog pokusa.

Pitanje bi bilo mnogo kvalitetnije da se tražilo objašnjenje zašto je biomasa plijesni na podlozi 2 manja u odnosu na podlogu 1, jer za ovako postavljeno pitanje grafički prikaz nije bio niti potreban, s obzirom da u zadatku piše da brojnost opada. Grafički prikaz je zbunjujući jer nije dobro označeno da se pod vrijeme misli na dane te da su crno rezultati na podlozi 1, a sivo na podlozi 2. Pitanje NB2-13b je najbolje riješeno od svih pitanja koja su zahtijevala kratki odgovor učenika, što potvrđuje veliku spretnost učenika i pri rješavanju pitanja koja nisu najbolje pripremljena.

Tablica 4 sadrži tri kognitivne kategorije kvalitete odgovora uz najčešće točne i netočne odgovore, te odgovore koji sadrže konceptualno nerazumijevanje zabilježeno kod 8 \% učeničkih odgovora (slika 6).

Tablica 4 Procjene kognitivnog značaja odgovora (razvrstanih u 3 kategorije kognitivne kvalitete odgovora: 0 - nema odgovora. 1 - pogrešno. 2 - konceptualno nerazumijevanje. 3 - točno) u pitanju NB2-13b

\begin{tabular}{cc}
\hline KOD & ODGOVOR \\
\hline $\mathbf{3}$ & Zbog toga što se hranjiva podloga maksimalno iskoristila te zbog nedostatka hranjivih tvari biomasa opada s vremenom. \\
$\mathbf{2}$ & Zato što bakterija proizvodi tvari koje sprječavaju rast plijesni i negativno djeluju na njih. \\
$\mathbf{1}$ & Zbog vanjskih utjecaja i okoliša. \\
$\mathbf{1}$ & Zbog nedostatka hrane i kisika. \\
$\mathbf{1}$ & Bakterija se hrani s plijesni. \\
$\mathbf{0}$ & Zato što joj ponestaje vode za razvoj \\
\hline
\end{tabular}

Grgurić, I., , Begić, V., Bastić, M., Lukša, Ž., Radanović, I. 2017. Kvaliteta pitanja i uspjeh srednjoškolskih sudionika natjecanja iz biologije u znanju. Educ. biol. 3, 1, 32-56. 
Na pitanje je uspješno odgovorilo 78 \% učenika, a procjena je bila $30 \%$, jer su učenici trebali zaključiti što se događa s plijesni na hranidbenoj podlogu, Na pitanje nije odgovorilo $4 \%$ učenika (slika 6), a najčešći točan odgovor bio je zbog iskorištenja hranjive tvari te se podudara s odgovorom koji je predviđen od strane državnog povjerenstva. Netočni odgovori su većinom vezani uz utjecaj bakterija na plijesni, to jest bakterije negativno utječu na plijesni.

U odgovorima konceptualnog nerazumijevanja vidljivo je da učenici nisu pažljivo pročitali tekst pitanja i uvodni tekst. Najčešći netočni odgovori također pokazuju da učenici nisu razumjeli tekst pitanja i da ne poznaju osnovne činjenice vezane za plijesni, bakterije i uvjete u kojima se uzgajaju kulture stanica. Uz točnost odgovora prema klasama utvrđena je statistički značajna razlika $\left(\chi^{2}=27,970 ; p=0,00 ; d f=6\right)$ koja potvrđuje bolju diskriminativnost zadatka, jer su uspješni učenici nudili pogrešan odgovor u vrlo malom udjelu koji se povećava prema nižoj klasi uspješnosti te dalje raste, pri čemu niti jedan učenik najslabije klase nije ponudio točan odgovor (slika 6).

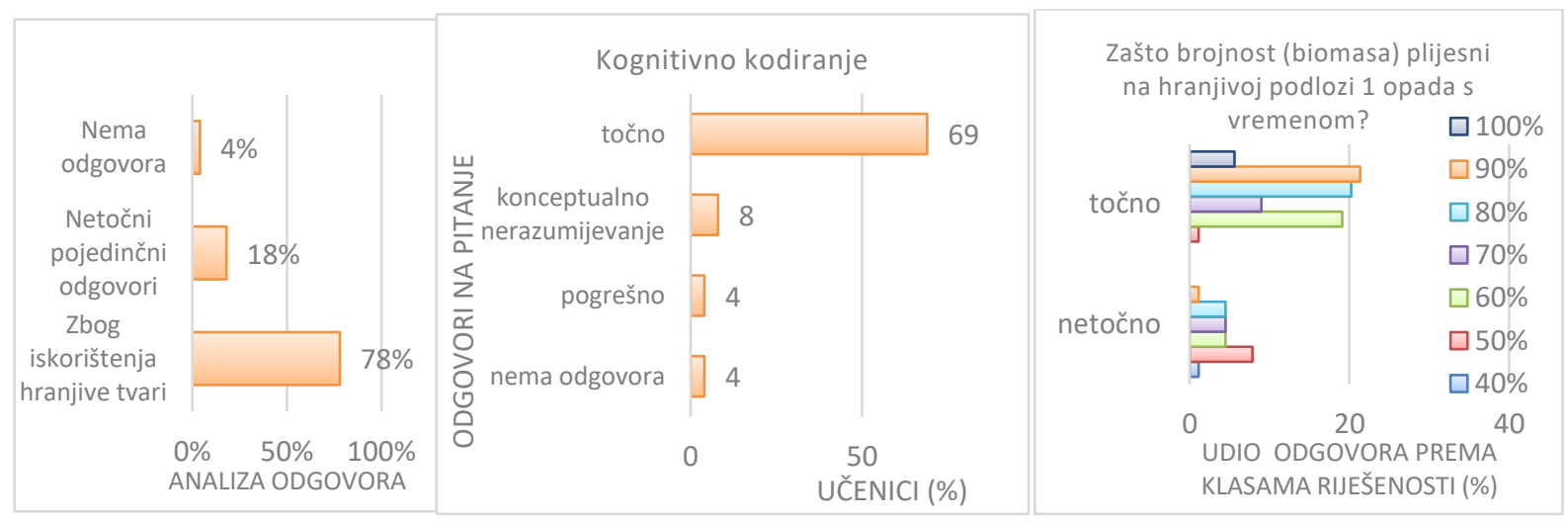

Slika 6 Analiza odgovora i točnosti pitanja NB2-13b za 2. razred

Pitanje NB3-20b izabrano je iz pisane provjere za 3. razred zbog manje riješenost od one procijenjene. Cijelo pitanje je interdisciplinarnog karaktera i povezano je s kemijom i fizikom. Riješenost ovog pitanja pokazuje da učenici imaju problema s pitanjima interdisciplinarnog karaktera, jer ne povezuju sadržaje STEM područja.

\section{PITANJE NB3-20b}

b) Izračunaj omjer oplošja i volumena tih stanica (ako pretpostavimo da se radi o stanicama oblika kugle) te objasni važnost omjera oplošja i volumena za te stanice, ako bi se promjer te stanice udvostručio.

Očekivani odgovor:

$\underline{d=8 \mu \mathrm{m}(r=4 \mu \mathrm{m})}$

$$
O: V=\text { ? }
$$

$O=4 \pi r^{2}$

$V=4 / 3 r^{3} \Pi$

$O=4 \times 3,14 \times 16 \mu \mathrm{m}^{2}$

$V=4 / 3 \times 64 \mu m^{3} 3.14$

$O=\underline{200,96 \mu \mathrm{m}^{2}}$

$V=\underline{267,95 \mu m^{3}}$

$O: V=200,96: 267.95 /: 267,95$

$$
O=4 \pi r^{2}
$$$$
V=4 / 3 r^{3} \Pi
$$

$O=4 \times 3,14 \times 64 \mu m^{2}$

$V=4 / 3 \times 512 \mu m^{3} 3,14$

$V=\underline{2143,57 \mu^{3}}$

$O: V=803,84: 2143.57 /: 2143.57$

$O=\underline{803,84{\mu m^{2}}^{2}}$

Obrazloženje: Što je stanica većeg volumena ima veću potrebu za izmjenom tvari i plinova pa mora biti veća $i$ površina izmjene. Omjer oplošja i volumena rastom stanica mijenja se u korist volumena, tj. smanjuje se površina, a samim tim izmjena tvari s okolinom. Vidljivo iz gornjeg računa je da oplošje stanice većeg promjera ima manju površinu izmjene u odnosu na volumen stanice.

Grgurić, I., , Begić, V., Bastić, M., Lukša, Ž., Radanović, I. 2017. Kvaliteta pitanja i uspjeh srednjoškolskih sudionika natjecanja iz biologije u znanju. Educ. biol. 3, 1, 32-56. 
Pitanje čine dvije čestice koje su samo tematski povezane uz krvne stanice, a ovo potpitanje otvorenog tipa srednje je težine, a očekuje se od učenika da sami izračunaju i obrazlože dobiveni rezultat uz prikaz konceptualnog razumijevanja odnosa površine i volumena kod živih bića. U prvom dijelu zadatka učenici primjenjuju vještine stečene u matematici, a u drugome vještine zaključivanja i razumijevanja dobivenih podataka u biološkom kontekstu. Potpitanje je vezano uz potpitanje $20 \mathrm{a}$, to jest u njemu se nalazi podatak da je promjer eritrocita $8 \mu \mathrm{m}$. Ovaj podatak učenici moraju koristiti iz prethodnog zadatka kako bi uspješno riješili prvi dio zadatka i izračunali omjer oplošja i volumena eritrocita te su na osnovi izračuna dali objašnjenje. Nije dobro zadatke vezati jedan na drugi i pripremati na način da točan odgovor iz jednog pitanja, čestice ili potpitanja utječe na riješenost drugog zadatka. Pitanje je važno za struku, srednje važno za život te potiče učenika na korištenje kritičkog razmišljanja i primjenu algoritama. Pitanje u svim segmentima srednje utječe na odgovor učenika.

Procjena točnosti pitanja bila je $40 \%$, ali pitanje je uspješno riješilo $15 \%$ učenika, a samo 4 \% učenika nije dalo odgovor (slika 7).

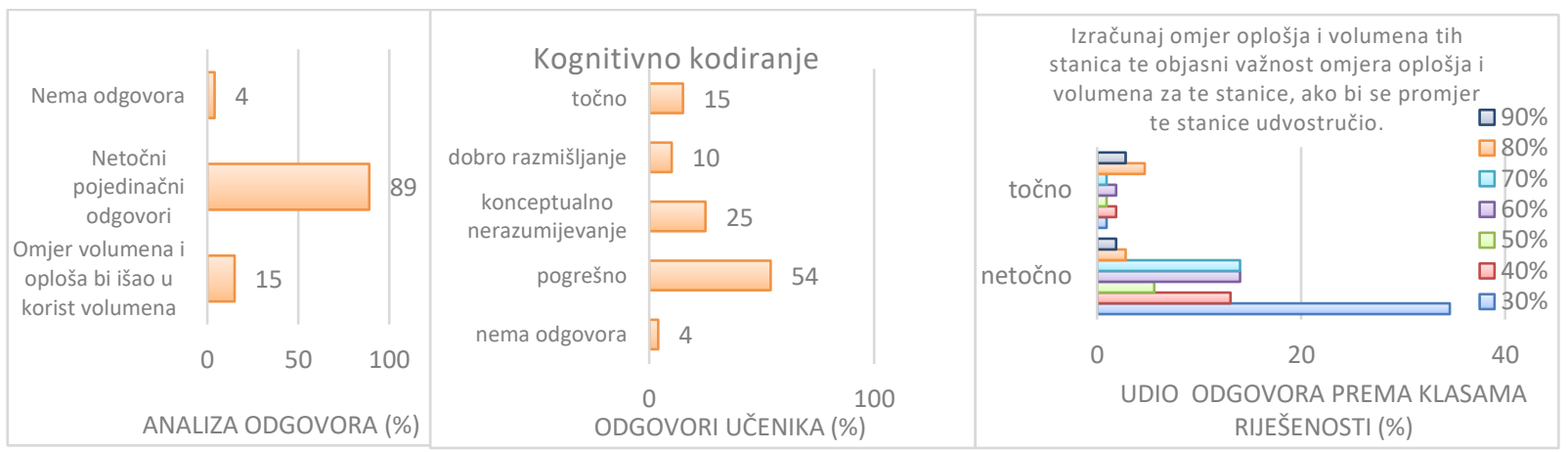

Slika 7 Analiza odgovora i točnosti pitanja NB3-20b za 3. razred

U tablici 5 nalaze se najčešći točni i netočni odgovori, odgovori koji sadrže konceptualno nerazumijevanje te odgovori koji pokazuju dobro razmišljanje učenika.

Tablica 5 Procjene kognitivnog značaja odgovora (razvrstanih u 4 kategorije kognitivne kvalitete odgovora: 0 - nema odgovora. 1 - pogrešno. 2 - konceptualno nerazumijevanje. 3-dobro razmišljanje 4 - točno) u pitanju NB3-20b

\begin{tabular}{|c|c|}
\hline KOD & ODGOVOR \\
\hline 4 & $\mathrm{O}: \mathrm{V}=0,75 / 1 \mu \mathrm{m}$; Ako bi se promjer stanice udvostručio. omjer oplošja i volumena bi bio manji \\
\hline 3 & $\begin{array}{c}\mathrm{O} / \mathrm{V}=3: 4 \text {. Ako bi se povećao promjer, površina za prijenos hranjivih tvari nije dovoljna za zadovoljavanje staničnih potreba i to bi } \\
\text { dovelo do stanične smrti }\end{array}$ \\
\hline 2 & $\begin{array}{l}\text { Stanice bi trebale imati veće oplošje od volumena kako bi mogle bolje prikupljati kisik. Ukoliko dođe do povećanja promjera } \\
\text { stanica će slabije moći prikupljati kisik jer će joj se povećati volumen u odnosu na oplošje. }\end{array}$ \\
\hline 1 & Ako bi se promjer te stanice udvostručio, omjeri svejedno ostaju jednaki tj. volumen i oplošje se proporcionalno povećavaju. \\
\hline 1 & $\begin{array}{l}\text { Pravilan omjer oplošja i volumena eritrocita je bitan jer ako se promjer te stanice udvostruči dolazi do bubrenja i pucanja } \\
\text { eritrocita. }\end{array}$ \\
\hline 0 & Nema odgovora \\
\hline
\end{tabular}

U 25 \% učeničkih odgovora (slika 7) vidljivo je da učenici ne razumiju vezu između volumena i oplošja te što bi promjena omjera oplošja i volumena značila za stanicu/organizam. U $10 \%$ učeničkih odgovora uočeno je dobro razmišljanje, ali i nedostatak vještine interpretacije da prenesu svoje razmišljanje na ispravan način. Uz točnost odgovora prema klasama utvrđena je statistički značajna razlika $\left(\chi^{2}=29,362\right.$; $p=0,00 ; d f=6)$ koja potvrđuje slabu diskriminativnost zadatka, a koja se može povezati s matematičkom predispozicijom za rješavanje zadatka, jer su uspješno riješili zadatak učenici iz svih klasa. Ipak učenici koji postižu $71 \%$ do $90 \%$ ukupno ostvarenih bodova na cijeloj provjeri, rješavaju ovaj zadatak u većem postotku (60 \%) u odnosu na druge klase (3\% - $15 \%)$. 
Pitanja NB4-1, NB4-3, NB4-12b izdvojena su iz provjere za 4. razred zbog manjeg postotka riješenosti od predviđenog, korištenja manje značajnih informacija pri izradi distraktora te uočenih miskoncepcija $\mathrm{i}$ konceptualnog nerazumijevanja. Pitanje NB4-1 i NB4-3 su vezana za genetiku i jasno se uočava da je to gradivo učenicima teško i nerazumljivo. Mnogi učenici nastavne sadržaje genetike uče površno i bez razumijevanja, a uočene su i miskoncepcije koje se protežu još iz osnovne škole, ali i prvog razreda srednje škole vezane za građu gena, kromosoma i kromatida. Pitanje NB4-12b izdvojeno je zbog konceptualnog nerazumijevanja čitanja podataka iz grafičkog prikaza. To je posljedica nedovoljne primjene istraživački usmjerene nastave ili primjera problemskih zadataka s grafičkim prikazom te što se ne posvećuje odgovarajuća pažnja točnoj interpretaciji podataka prikazanih grafičkim prikazom.

\section{PITANJE NB4-1}

Koja je tvrdnja o ljudskom genomu točna?

a) Sadrži otprilike 35125 gena

b) Samo 5\% prepisuje se u molekule RNA.

c) To je za sad najduži otkriveni genom živih bića.

d) Sastoji se od 22 autosoma i jedne kopije spolnih kromosoma. (T)

e) Po njegovoj veličini možemo odrediti broj gena u genskoj uputi.

Srednje teško reproduktivno pitanje višestrukog izbora $s$ jednim točnom odgovorom jače utječe na odgovor učenika (tablica 3). Procjena riješenosti pitanja je $50 \%$, ali pitanje je uspješno riješilo samo $9 \%$ učenika (slika 8). Uzrok loše riješenosti ovog pitanja je učenička nepažnja prilikom čitanja ponuđenih odgovora, to jest drugi dio točnog odgovora (jedne kopije spolnih kromosoma) je izrečen na drukčiji način od uobičajenog tumačenja pri poučavanju i učenici su ga odmah isključili. Ovo pitanje pokazuje kako promjena jedne riječi u pitanju utječe na riješenost pitanja. Da je umjesto kopije kromosoma pisalo jednog gonosoma (spolnog kromosoma), riješenost bi zasigurno bila bolja. S obzirom da u ovom slučaju primjena znanja uključuje samo pronalazak točnog odgovora, a distraktori a) i c) imaju karakter odgovora dodatne informacije i detalja koji se temelji na memoriranju, nije neobično da je manji broj učenika točno riješio zadatak. Najbolji distraktor u ovom pitanju je odgovor $a$ ) kojega je odabralo $68 \%$ učenika. Učenici su izabrali ovaj odgovor jer im je ponuđen broj, a budući da im niti jedan drugi odgovor nije bio privlačan, njega su odabrali vodeći se iskustvom stečenim na pisanim provjerama u prošlim natjecanjima. Distraktor $c$ ) je zaokružilo samo $4 \%$ učenika i njega treba promijeniti (slika 8).

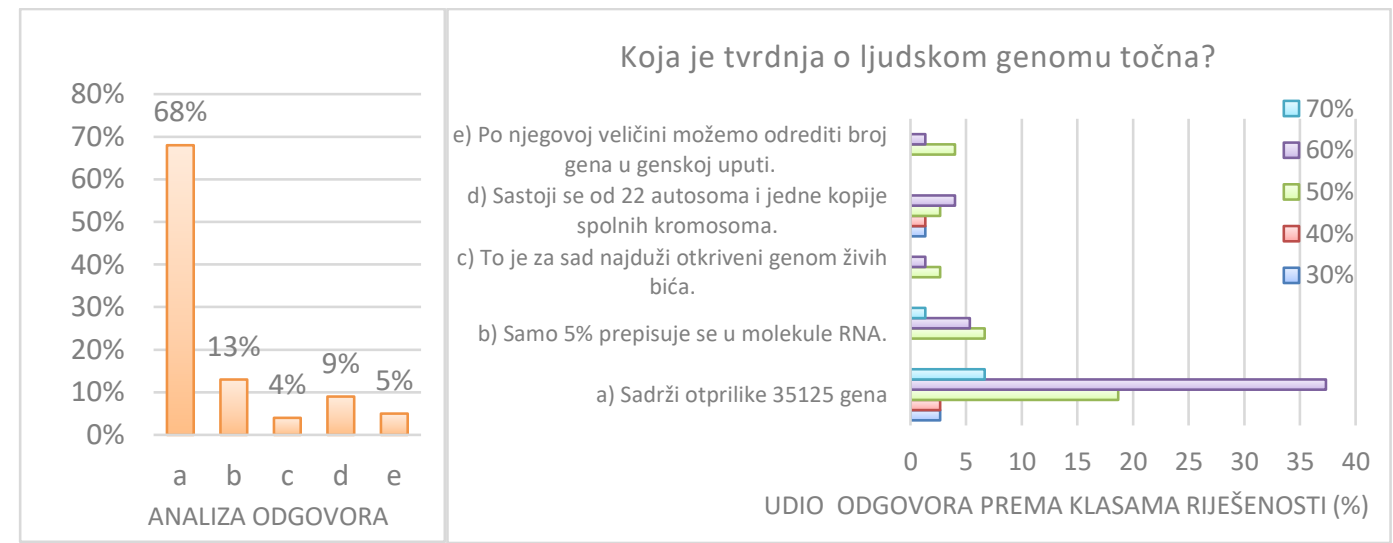

Slika 8 Analiza odgovora i točnosti pitanja NB4-1 za 4. razred

Prema klasama uspješnosti (slika 8) utvrđena je statistički značajna razlika $\left(\chi^{2}=10,658 ; p=0,031 ; d f=4\right)$ koja potvrđuje upitnu vrijednost zadatka, jer su ga točno riješili malobrojni učenici iz svih klasa 
uspješnosti, pri čemu ga nije točno riješio niti jedan od najuspješnijih učenika u rješavanju svih zadataka pisane provjere.

\section{PITANJE NB4-3}

Diploidni broj kromosoma kukuruza je 20. Koliko se molekula DNA može očekivati u jezgri stanice sekundarnog endosperma pšena neposredno prije mitotske diobe?
a) 10
b) 20
c) 40
d) $60(T)$
e) 80

Teško pitanje višestrukog izbora s jednim točnim odgovorom dobre je kvalitete (tablica 3), a provjerava primjenu znanja učenika. Važno je za struku, a ni u jednom elementu ne utječe na odgovor učenika. Procjena točnosti pitanja je $40 \%$, ali pitanje je uspješno riješilo samo $5 \%$ učenika. Mogući razlog loše riješenosti je da učenici ne znaju primijeniti teoriju na zadatku, jer se ovakav tip zadataka na nastavi rijetko zadaje i rješava.

Distraktori c) (43 \%) i b) (41 \%) su podjednako zastupljeni u odgovorima učenika (slika 9). To su najčešći odgovori zato jer su učenici udvostručili broj kromosoma i dobili odgovor $c$ ), a u odgovoru $b$ ) učenici nisu razmišljali da diploidno znači da su kromosomi u parovima. Pogreška je u tome što se gametogeneza kod biljaka odvija na drukčiji način (polenovo zrnce sadrži 2 generativne i 1 vegetativnu jezgru, a sve su haploidne) čemu se poklanja manja važnost pri poučavanju, a time i pri učenju te se životni ciklusi kao i odnos haploidno/diploidno ne povezuju konceptualno.

Prema klasama uspješnosti (slika 9) uz točnost odgovora nije utvrđena statistički značajna razlika $\left(\chi^{2}=5,959 ; p=0,202 ; d f=4\right)$ koja potvrđuje postojanje problema, jer zadatak rješava vrlo mali broj učenika neovisno o klasi uspješnosti, pri čemu niti jedan od najuspješnijih učenika nije ponudio točan odgovor (slika 9).
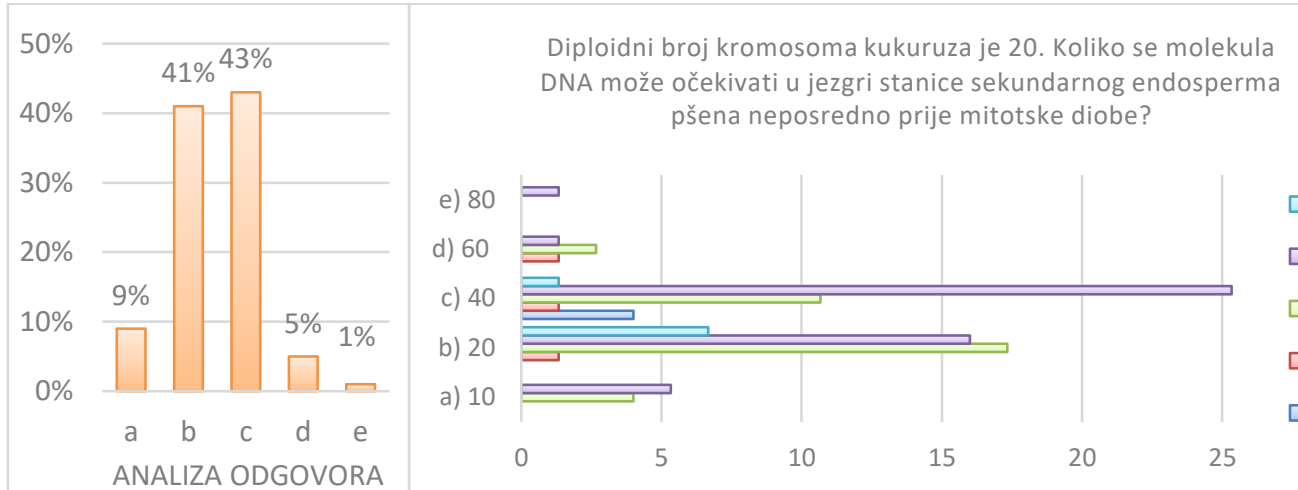

Slika 9 Analiza odgovora i točnosti pitanja NB4-3 za 4. razred

PITANJE NB4-12b

Apoptin je virusni protein koji izaziva apoptozu u ljudskim tumorskim stanicama. Za uspješan unos gena za apoptin $u$ tumorsku stanicu može se kao vektor koristiti adenovirus. Na donjem grafu prikazana je ovisnost rasta tumorskih stanica pluća o multiplicitetu infekcije adenovirusom (MOI) u ljudi.

b) Kakav učinak ima tretman kontrolnim vektorom pri MOI

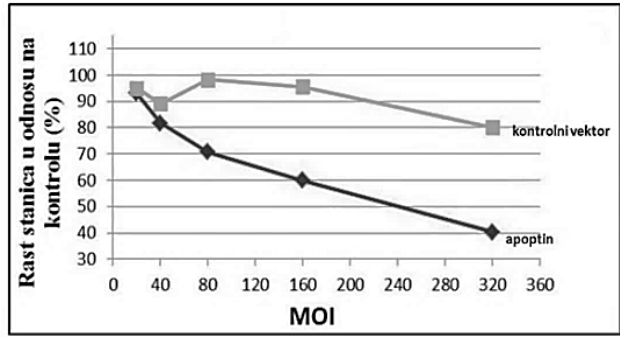
manjem od 160 ?

Grgurić, I., , Begić, V., Bastić, M., Lukša, Ž., Radanović, I. 2017. Kvaliteta pitanja i uspjeh srednjoškolskih sudionika natjecanja iz biologije u znanju. Educ. biol. 3, 1, 32-56. 
Očekivani odgovor: Tretman kontrolnim vektorom MOI nema nikakav učinak (ne djeluje) pri vrijednostima manjim od 160.

Srednje teško, kvalitetom dobro pitanje otvorenog je tipa na koje se odgovara objašnjenjem ili jednom riječi s obzirom na uvodni tekst i priloženi grafički prikaz. Pitanje provjerava primjenu čitanja grafičkog prikaza u najnižem obuhvatu. Pitanje je važno za struku i propisani program, a na bolju riješenost pitanja utječe razumijevanje i logičko zaključivanje učenika.

Najčešći priznati točan odgovor od strane nastavnika bio je: učinak je slab, a da se taj odgovor nije priznavao kao točan, točnost pitanja bi bila $4 \%$, jer je samo toliko učenika odgovorilo da nema nikakvog utjecaja (slika 10). Pitanje je točno riješilo samo $33.3 \%$ učenika, a procjena riješenosti je bila $50 \%$. Tako slaba riješenost vjerojatno je posljedica nerazumijevanju čitanja uvodnog teksta i grafičkog prikaza te pokazuje da učenicima treba više praktičnog rada i vježbanje rješavanja zadataka u kojima se nalaze grafički prikazi, a autori zadataka trebaju paziti da se u uvodnom tekstu koriste nužne informacije opisane i prikazane učenicima prihvatljivim rječnikom. No s obzirom da je ovo pitanje za natjecanje učenika 4. razreda gimnazije, za potrebe dijagnosticiranja izuzetno uspješnih učenika prihvatljiv je pristup korišten u pripremi ovog zadatka.

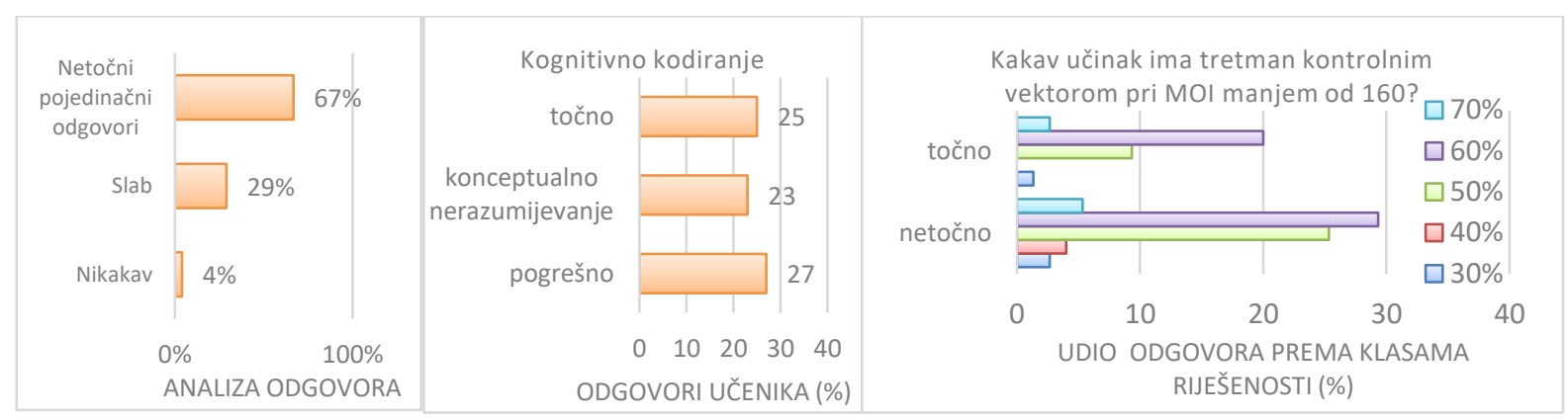

Slika 10 Analiza odgovora i točnosti pitanja NB4-12b

Svojim odgovorima je $23 \%$ učenika pokazalo da konceptualno ne razumiju zadatak (slika 10). Ti učenici posjeduju vještinu čitanja grafičkog prikaza, ali ne posjeduju vještinu interpretacije. $27 \%$ učenika je dalo krivi odgovor koji uopće nije povezan sa stanjem koje opisuje grafički prikaz. Ovi učenici ne posjeduju vještinu čitanja i objašnjavanja grafičkog prikaza, već žele ponuditi odgovor kako su navikli pretražujući i nudeći donekle suvisao odgovor iz svoje memorije. Samo 25 \% učenika je točno protumačilo grafički prikaz, ali i među njima postoji razlika u vještini interpretacije, vjerojatno utjecana iskustvom primjene pri rješavanju sličnih zadataka tijekom nastave. Točnost odgovora prema klasama ne upućuje na statistički značajnu razliku $\left(\chi^{2}=3,078 ; p=0,545 ; d f=4\right)$, ukazujući na slabiju mogućnost razlučivanja uspješnih od neuspješnih učenika te na postojanje problema u rješavanju zadatka čak i kod najuspješnijih učenika. Omjeri riješenosti unutar klasa su podjednaki uz manja variranja prema srednjoj riješenosti po klasama od $34 \%$, a mali broj učenika u slabijim malobrojnim klasama riješenosti (40\%) ne remeti sklad odnosa u drugim posebno brojnim klasama (50\% i 60\%).

\section{Analiza utjecaja iskustva na procjenu kvalitete pitanja}

Procjene kvalitete pitanja subjektivnog su karaktera, ali vježbom postaju objektivnije, a uočena su veća odstupanja kod nastavnika s iskustvom u pisanju pitanja za natjecanje (eksperata) i nastavnika koji to iskustvo ne posjeduju. Prema tablici 7 kod procijene riješenosti pitanja uočene su srednje razlike između nastavnika koji posjeduju iskustvo pisanja provjera za natjecanje i nastavnika koji nemaju nikakvo

Grgurić, I., , Begić, V., Bastić, M., Lukša, Ž., Radanović, I. 2017. Kvaliteta pitanja i uspjeh srednjoškolskih sudionika natjecanja iz biologije u znanju. Educ. biol. 3, 1, 32-56. 
iskustvo u tim aktivnostima. Razlika između nastavnika bez iskustva u pisanju pitanja za natjecanje također je srednje vrijednosti.

Tablica 6 Srednja vrijednost stručne procjene kvalitete pitanja s obzirom na iskustvo nastavnika u pripremi i procjeni zadataka pisane provjere te korelativna povezanost unutar kategorije procjene $\left(N_{\text {do 5. g. }}=5, N_{\text {više od 5.g. }}=3, N_{\text {eksperti }}=2\right)$

\begin{tabular}{|l|c|c|c|}
\hline & \multicolumn{3}{|c|}{ Pearsonov indeks korelacije $(\boldsymbol{r})$} \\
\hline Nastavnici & $\begin{array}{c}\text { do } 5 \mathrm{~g} . \text { i više } \\
\text { od } 5 \mathrm{~g} .\end{array}$ & $\begin{array}{c}\text { do } 5 \mathrm{~g} . \mathrm{i} \\
\text { eksperti }\end{array}$ & $\begin{array}{c}\text { više od } 5 \mathrm{~g} . \\
\text { i eksperti }\end{array}$ \\
\hline Procjena riješenosti pitanja / \% & 0,40 & 0,41 & 0,36 \\
\hline Težina pitanja & 0,78 & 0,50 & 0,38 \\
\hline Razina pitanja & 0,69 & 0,60 & 0,34 \\
\hline A - važnost pitanja za struku & 0,51 & $-0,07$ & $-0,13$ \\
\hline B - važnost pitanja za život & 0,75 & 0,52 & 0,40 \\
\hline C - važnost pitanja za propisani program & 0,48 & 0,00 & 0,00 \\
\hline D - kritičko mišljenje & 0,81 & 0,10 & 0,01 \\
\hline E - razumljivost & 0,78 & 0,19 & 0,19 \\
\hline F - konstrukcija pitanja & 0,82 & 0,17 & 0,13 \\
\hline G - logičko zaključivanje & 0,71 & 0,42 & 0,35 \\
\hline H - dodatno učenje & 0,83 & 0,25 & 0,27 \\
\hline
\end{tabular}

Uočeno je veliko slaganje $(r=0,79)$ procjena mladih nastavnika i nastavnika s duljim radnim stažem te slabo slaganje eksperata i obje grupe nastavnika. Nešto više se podudaraju procjene eksperata i mladih nastavnika, posebno pri procjeni utjecaja pitanja na odgovor učenika $(r=0,27)$, iako su i ostale procjene u sličnom odnosu razlika. U usporedbi procjena obiju skupina nastavnika bez iskustva u pripremi zadataka prema odrednicama kvalitete u odnosu na nastavnike koji su eksperti u pripremi zadataka pisane provjere, može se uočiti srednja povezanost za kategorije utjecaja logičkog zaključivanja na odgovor učenika te važnosti pitanja za život, kao i pri procjeni riješenosti, razine i težine pitanja, a najslabije se mogu povezati procjene važnosti pitanja za propisani program te struku kod eksperata $\mathrm{i}$ nastavnika (tablica 7). Zabilježene razlike u slaganju ukazuju da nastavnici bez iskustva u procjeni kvalitete zadataka, slabije procjenjuju važnost pitanja za razvoj prirodoslovne pismenosti, pri čemu su zabilježene manje razlike između mladih nastavnika i eksperata $(M=-0,08 \pm 0,38)$ u odnosu na nastavnike $s$ duljim radnim stažem $(M=-0,20 \pm 0,38$ ). Pri usporedbi procjena eksperta i nastavnika $s$ većim radnim stažem, a bez iskustva u pripremi zadataka, zabilježene su veće razlike $\mathrm{i}$ to najviše $\mathrm{u}$ kategoriji procjene važnosti pitanja za razvoj prirodoslovne pismenosti $(r=0,11)$.

Prema Fleiss kappa (к) vrijednosti (tablica 9) u procjenama vrijednosti za treći i četvrti razred nema nikakvih slaganja kod nastavnika početnika. U prvom razredu slaganje je umjereno, a u drugom značajno. Kod iskusnih nastavnika nema nikakvih slaganja u vrijednostima za drugi, treći i četvrti razred, a za prvi razred slaganja su slaba. Kod iskusnih nastavnika i nastavnika početnika vrijednosti se najviše podudaraju u četvrtom razredu.

Tablica 7 Fleiss kappa (к) vrijednosti slaganja procjena prema iskustvu

\begin{tabular}{ccccc}
\hline Kappa (к) & 1.G & 2.G & 3.G & 4.G \\
\hline Početnici & 0,49 & 0,63 & 0,14 & 0,07 \\
Iskusni & 0,25 & 0,13 & $-0,09$ & 0,02 \\
\hline
\end{tabular}

Analiza utjecaja pojedinog elementa procjene Spearmanovim indeksom korelacije $(\rho)$ ukazuje da najveći utjecaj na Fleiss kappa ( $\mathrm{k}$ ) vrijednosti slaganja procjena prema iskustvu ima kategorija utjecaj pitanja na odgovor (tablica 12). Kod početnika $i$ iskusnih nastavnika uočava se da što je pitanje manjeg utjecaja neslaganje je veće, a kod eksperta kad je pitanje s manjim utjecajem na odgovor tada su slaganja u procjeni veća. Pošto je eksperata bilo samo dvoje, ostvareno je umjereno do značajno slaganje (tablica

Grgurić, I., , Begić, V., Bastić, M., Lukša, Ž., Radanović, I. 2017. Kvaliteta pitanja i uspjeh srednjoškolskih sudionika natjecanja iz biologije u znanju. Educ. biol. 3, 1, 32-56. 
9) što potvrđuje ipak prisutne manje razlike u procjenama te ističe potrebu uključivanja većeg broja i iskusnih nastavnika pri procjeni kvalitete pitanja kako bi se povećala pouzdanost procjene.

Tablica 8 Spearmanov indeks korelacije $(\rho)$ Fleiss Kappa koeficijenta $(\kappa)$ kao mjere međusobnog podudaranja stručne procjene kvalitete pitanja nastavnika s obzirom na njihovo iskustvo i pripremi i procjeni zadataka te elemenata procjene

\begin{tabular}{|c|c|c|c|}
\hline Indeks korelacije ( $\rho)$ & Početnici (к) & Duže radno iskustvo (к) & Eksperti (к) \\
\hline Početnici (к) & 1 & & \\
\hline Duže radno iskustvo (к) & 0,75 & 1 & \\
\hline Eksperti (к) & $-0,74$ & $-0,50$ & 1 \\
\hline Težina pitanja & $-0,96$ & $-0,79$ & 0,53 \\
\hline Razina pitanja & 0,05 & 0,25 & $-0,64$ \\
\hline Prirodoslovna pismenost (PP) & $-0,33$ & $-0,31$ & $-0,39$ \\
\hline Utjecaj pitanja na odgovor (U) & $-0,98$ & $-0,86$ & 0,74 \\
\hline Kvaliteta pitanja & $-0,66$ & $-0,59$ & $-0,02$ \\
\hline
\end{tabular}

\section{RASPRAVA}

Nakon dobivenih rezultata analiziranih pitanja nameće se pitanje na što ona ukazuju o pisanim provjerama za Županijska natjecanja i o znanju naših učenika. Prije nego se krene u raspravu treba uzeti $\mathrm{u}$ obzir da je $\mathrm{u}$ analizi pitanja individualno sudjelovalo deset profesora $\mathrm{s}$ različitim radnim stažem $\mathrm{i}$ iskustvom u pisanju pitanja te da učenici koji sudjeluju na natjecanjima pripadaju u skupinu nadprosječno uspješnih ili nadarenih učenika koji su ostvarili $20 \%$ najboljih rezultata unutar svojih županija.

Najviše učenika iz trećeg razreda sudjelovalo je na natjecanju iz biologije, a najmanje iz četvrtog razreda, dok je prema spolu sudjelovalo više djevojčica od dječaka. Prema Garašić (2012) to je očekivano, jer se interes djevojčica za nastavu biologije naglo povećava u sedmom razredu osnovne škole i nastavlja dalje kroz srednju školu, dok se interes kod dječaka za biologiju gubi tijekom školovanja. Allen i Tannera (2002) u svom istraživanju navode da je interes dječaka i djevojčica vezan za ljudsko tijelo, zdravstveni odgoj te modernizaciju i tehnologiju u biologiji podjednak, dok interes dječaka prema zoologiji i botanici opada više nego kod djevojčica. To se može povezati i s rezultatima dobivenima ovim istraživanjem. $U$ trećem i četvrtom razredu ima više dječaka nego u drugom ili prvom razredu. $U$ tim razredima se obrađuju teme koje su njima zanimljivije i bliže. Prema uspješnosti dječaci su bili uspješniji od djevojčica u svim razredima. Najbolja riješenost provjera je bila u drugom, a najlošija u četvrtom razredu. Većina učenika u svim razredima imala je riješenost 58 \%. Najviše učenika pripada u šestu klasu riješenosti (raspon od $51 \%$ do $60 \%$ ). Najmanje učenika pripada u treću i četvrtu klasu. Iznimka je treći razred u kojem najviše učenika pripada u treću a najmanje u devetu klasu. Lujan i DiCarlo (2006) u svom istraživanju navode da se kvaliteta pisanih provjera očituje u njihovoj riješenosti.

U prethodnim istraživanjima Lukša (2011) navodi da većina učenika koji sudjeluju na natjecanjima ima prosječnu riješenost provjera, a značajne razlike se javljaju u rješavanju pitanja treće kognitivne razine, jer će ih samo najuspješniji učenici uspjeti riješiti što potvrđuju rezultati i ovog istraživanja, ako se uzmu u obzir teži zadaci koji provjeravaju konceptualno razumijevanje. Prema PISA projektu (Braš Roth i sur, 2008; 2014) rezultati koji su dobiveni iz prirodoslovne pismenosti pokazuju da hrvatski učenici imaju najbolje rezultate iz pitanja koja su na prvoj razini, a u pitanjima koja traže rješavanje problema naši učenici nalaze se na začelju. Rezultati dobiveni PISA projektom (Braš Roth i sur, 2010; 2017) podudaraju se s rezultatima dobivenim u ovom radu. Čim se zadatak postavi na većoj kognitivnoj razini rezultati su lošiji i uočava se konceptualno nerazumijevanje učenika. Pisane provjere za natjecanja sastavljene su u skladu s naputcima (Radanović i sur, 2013), osim što u trećem razredu nema zastupljene treće kognitivne razine. To je posljedica izostanka metodičke recenzije pitanja od strane eksperata u pripremi zadataka

Grgurić, I., , Begić, V., Bastić, M., Lukša, Ž., Radanović, I. 2017. Kvaliteta pitanja i uspjeh srednjoškolskih sudionika natjecanja iz biologije u znanju. Educ. biol. 3, 1, 32-56. 
na nacionalnoj razini, jer autori kao i većina neiskusnih nastavnika razine određuju na osnovu individualnog iskustva rada s učenicima. Lukša (2011) ističe da najčešće dolazi do razlika u određivanju pitanja prve i druge kognitivne razine, jer profesori često pitanje zbog određene težine svrstavaju u veću kognitivnu razinu iako ono provjerava čistu reprodukciju. To se najbolje može uočiti u provjerama za županijsko natjecanje i državnu maturu. Ovaj problem nije zamijećen samo kod hrvatskih nastavnika, jer su o njemu pisali i drugi autori poput Allen i Tannera (2002). Lukša (2011) i Garašić (2012) predlažu da se u nastavu treba uvodi više problemskih zadataka koji se temelje na razvoju vještina i stvaranju kritičkog mišljenja. Također Lujan i DiCarlo (2006) ističu da aktivno sudjelovanje učenika u nastavi i njihova uključenost u proces učenja rezultira konceptualnim razumijevanjem i primjenom znanja koja im ostaju kao trajna znanja, dok je reproduktivno znanje podložno kratkoročnom pamćenju i brzom zaboravljanju.

Od odabranih pitanja četiri je pitanja višestrukog izbora s jednim ili dva točna odgovora. Higham i Arnold (2007) smatraju da se u ovakvim pitanjima može doći do odgovora na temelju eliminacije distraktora i logičkog razmišljanja. Također, učenici u ovakvom tipu zadataka u većoj mjeri pogađaju točne odgovore nego što se oslanjaju na vlastito znanje. Bez obzira na nedostatke, ovaj tip pitanja je vrlo koristan za pisane provjere znanja, jer provjerava veliki broj učenika u malom vremenskom roku, izbor točnog odgovora sveden je na 25 \% te se odgovori lagano analiziraju (Garašić, 2012). Pitanja višestrukog izbora s dva točna odgovora pri tome su slabije kvalitete i vrlo često su prema ponuđenim odgovorima nehomogena te $u$ analizi odgovora ne pružaju stvarnu sliku o kvaliteti razumijevanja učenika o ispitivanim konceptima. Četiri analizirana pitanja su otvorenog tipa i zahtijevaju učenički odgovor na temelju analize uvodnog teksta ili grafičkog prikaza, a autori su u njihovu sastavljanju na osnovu procijenjene kvalitete uspješniji u odnosu na sastavljanje ostalih tipova pitanja u pisanim provjerama znanja na natjecanju iz biologije.

Prilikom unošenja učeničkih odgovora za obradu podataka uočena je sličnost između odgovora učenika koji dolaze iz iste županije, što je možda produkt prepisivanja. Također učenici se pripremaju za natjecanje i otprilike znaju kakva pitanja otvorenog tipa mogu očekivati na temelju prijašnjih iskustva u natjecanju te pitanja iz prethodnih godina natjecanja za pojedini razred pa više vježbaju rješavanje pitanja takvog tipa. Barksdale-Ladd i Thomas (2000) naglašavaju važnost pripreme i poznavanja načina provjeravanja te je zbog toga učenicima potrebno predstaviti tipove pitanja/zadataka kakvi će se primjenjivati u natjecanju. Pitanja otvorenog tipa većinom se sastoje od uvodnog teksta kojeg učenici površno pročitaju ili ne razumiju, a to pridonosi većem postotku netočnih odgovora. Isti problem su uočile Garašić (2012) i Lukša (2011) u svojim istraživanjima te navode da uvodni tekstovi u pisanim provjerama ne bi trebali biti predugački niti sadržavati informacije i riječi nepotrebne za rješavanje zadatka. U prilog tome ide i istraživanje PISA projekta u kojem je vidljivo da je slaba rješivost pitanja posljedica poteškoća u čitanju, razumijevanju pročitanog i na kraju interpretaciji odgovora (Braš-Roth i sur, 2008).

Na kvalitetu najslabije riješenih pitanja veliki utjecaj imaju kategorije utjecaja na rješavanje pitanja kao i važnost pitanja za poticanje prirodoslovne pismenosti, a najveći utjecaj ima važnost pitanja za struku. Pitanja najbolje kvalitete pokazuju vrlo veliku povezanost $s$ kategorijom važnosti pitanja za poticanje prirodoslovne pismenosti kod učenika i svim njenim elementima procjene izuzev srednje povezanosti s poticanjem kritičkog mišljenja, što ukazuje da najkvalitetniji zadaci još nedovoljno potiču učenike u razmišljanju i konceptualnom povezivanju. Kod takvih pitanja veću pažnju treba usmjeriti na oblikovanje i razumljivost pitanja (Braš Roth i sur, 2008) te smanjiti utjecaj samo logičkog razmišljanja učenika bez

Grgurić, I., , Begić, V., Bastić, M., Lukša, Ž., Radanović, I. 2017. Kvaliteta pitanja i uspjeh srednjoškolskih sudionika natjecanja iz biologije u znanju. Educ. biol. 3, 1, 32-56. 
stvarne primjene znanja, čime će se omogućiti da učenici pri rješavanju zadataka kritički promišljaju. Dobro je što autori nastoje da takva pitanja ipak ne budu uvijek učenicima preteška. Obzirom da se radi o natjecanju učenika zabilježen je manji, a prihvatljiv bi bio i srednji utjecaj dodatnog učenja učenika na uspješnost u rješavanju pitanja posebno na državnoj razini natjecanja, ali samo u svrhu konceptualnog proširivanja temeljnog znanja redovne nastave primjenjivog u rješavanju složenijih problemskih situacija predstavljenih u zadacima, a ne opterećivanju učenika memoriranjem dodatnih pojmova. U odnosu na postignutu riješenost zadataka utvrđena je veća povezanost kvalitetnijih pitanja s procjenom riješenosti u odnosu na pitanja slabije kvalitete, što je još jedna potvrda o kvaliteti zadataka. Težina pitanja i kognitivna razina srednje su obrnuto proporcionalno povezane s ostvarenom riješenosti što je i za očekivati, kako bi se provjerom moglo dobro izlučiti najuspješnije učenike. Bolja povezanost kod kvalitetnijih pitanja potvrđuje važnost pripreme pitanja uz uvažavanje elemenata procjene kvalitete, a posebno primjene kritičkog razmišljanja u zadacima provjere konceptualnog razumijevanja.

Miskoncepcije su većinom vezane za pitanja koja provjeravaju koncepte unutar ključnog koncepta molekularno ustrojstvo živih organizama (molekula DNA, RNA, aminokiseline) i nasljeđivanje na razini organizma (gen, kromosomi, mejoza), a konceptualno nerazumijevanje javlja se u zadacima koji su interdisciplinarnog karaktera i zahtijevaju primjenu znanja i vještina iz kemije i fizike. Garašić (2012) i Lukša (2011) također su uočile da najčešće miskoncepcije i konceptualno nerazumijevanje nastaje upravo u tipu zadataka koji provjeravaju koncepte vezane za nasljeđivanje. One zaključuju da je to gradivo teško i apstraktno učenicima te ga učenici za provjeru znanja nauče bez razumijevanja. Tome u prilog idu i rezultati prvog i četvrtog razreda, jer je u svim razredima uspješnost u rješavanju ovakvih zadataka ispod prosjeka. Flores i sur. (2003) također napominju kako učenici različite dobi imaju problema s razumijevanjem procesa koji se događaju u stanici, a uključuju pojmove gen, kromosom, DNA, aminokiseline, proteini i stanična dioba. Pitanja NB4-1 te NB4-3 odgovaraju problemu koji uključuje miskoncepcije vezane za DNA, aminokiseline, gen i staničnu diobu, a imaju izrazito malu riješenost u odnosu na procijenjenu od strane nastavnika. Nastavnici nisu svjesni što učenici stvarno znaju, a na čemu bi još trebalo poraditi pri čemu se potvrđuje i zaključak Lukša i sur. (2014) da nastavnici imaju tendenciju očekivati bolje rezultate učenika na pitanja za koja smatraju da su važnija. U zadacima NB4-1 (I. razina, težina 2) i NB4-3 (II. razina, težina 3) učenici pokazuju da imaju problema s razumijevanjem genetike i osnove nasljeđivanja. Činjenica je da nastavnici troše veliku količinu vremena na gradivo genetike, jer znaju da je ono teško i zahtjevno za učenike, a sve u cilju uspješne prolaznosti na pisanim provjerama vanjskog vrednovanja (Ristić-Dedić i sur, 2011). Međutim, činjenica je da su rezultati različiti i da usprkos naporima nastavnika postoje grupe učenika koji sve razumiju, kao i oni koji su se totalno pogubili $u$ rješavanju ili nisu ni pokušali zaključivši da je to teško. Knight sa suradnicima (2005) smatra da je razlog uniformni pristup pri poučavanju te predlaže da se nastavi pristupi na drukčiji, to jest vizualni i sistematičniji način. Oni smatraju da bi takav pristup omogućio učenicima da bolje povežu gradivo genetike s karakteristikama organizama. U zadatku NB4-1 uočeno je da je riječ kopija bila glavni krivac za veliku netočnost u ovom zadatku, jer se ta riječ ne upotrebljava u nastavi i učenici su odmah eliminirali taj odgovor. U pitanju NB4-3 učenici imaju poteškoća s razumijevanjem gametogeneze kod biljaka. Garašić (2012) napominje da učenici pokazuju jako mali interes za botaniku, jer obiluje velikom količinom informacija i pojmova. To je u ovom pitanju uzrokovalo jako loš rezultat. Učenici nisu obratili pozornost da se radi o endospermu pšena i primijenili osnovu vezanu za razvojni ciklus biljaka. Osim toga uočeno je nerazumijevanje pojma kromosoma, kromatida i DNA.

Grgurić, I., , Begić, V., Bastić, M., Lukša, Ž., Radanović, I. 2017. Kvaliteta pitanja i uspjeh srednjoškolskih sudionika natjecanja 
Pitanja NB2-13b i NB4-12b upozoravaju na probleme predugačkog uvodnog teksta koji ne sadrži informacije vezane uz pitanje i poteškoće čitanja podataka iz grafa. U pitanjima za prvi razred zabrinjava činjenica da učenici imaju problema s definiranjem zavisne i nezavisne varijable što je potvrđeno i pri rješavanju zadataka na državnoj maturi (Radanović i sur, 2017b). To dokazuje da u nastavi biologije ima premalo praktičnog rada, izvanučioničke $i$ istraživačke nastave na kojoj bi učenici upoznali i primijenili osnovne spoznaje vezane uz istraživački rad. Razlika u rezultatima između provjera učenika koji su sudjelovali s istraživačkim radovima i učenika koji su samo prisustvovali na pisanoj provjeri ide u korist učenika koji su sami pisali istraživački rad i koristili zavisne i nezavisne varijable u svome radu te su ostvarili bolju riješenost u tom dijelu provjere. Na nedostatak istraživačke nastave upozoravaju i Lujan i DiCarlo (2006) koji tvrde da učenici moraju sami provesti istraživanje i na temelju njega izvesti zaključke da bi upoznali stvarnu stranu biologije. Pitanje NB2-13b je najbolje riješeno od svih pitanja koja su zahtijevala kratki odgovor učenika. Tijekom klasifikacije pitanja uočeno je da je glavni uzrok netočnih odgovora neprecizno čitanje uvodnog teksta i grafičkog prikaza. Dobra riješenost može se povezati s činjenicom da je bakteriologija zanimljiva učenicima te je većina učenika, koji pripadaju u visoko motiviranu skupinu s kojom nastavnici rado dodatno rade, radila nacjepljivanje bakterija na hranjivu podlogu. Zabrinjava odgovor učenika koji kažu nestalo im je kisika, a u tekstu je navedeno da su podloge inkubirane. Labov i suradnici (2010) ističu da povezivanje biologije sa stvarnim problemima i njihovo rješavanje primjenom znanja te uključivanjem učenika u aktivni proces učenja doprinosi trajnom $i$ smislenom usvajanju znanja. Radi razvoja tehnologije, a pogotovo farmaceutske industrije ovo gradivo je još važnije za svakodnevni život učenika i treba u nastavnoj praksi slijediti dokaze (Labov i sur, 2010) da učenici koji aktivno sudjeluju u raspravama zadržavaju informacije duže od učenika koji su pasivni slušači. Pitanje NB4-12b zabrinjava jer njegova mala riješenost ukazuje da učenici četvrtih razreda ne posjeduju vještinu interpretacije podataka iz grafičkog prikaza. Simpson i Arnold (1982) navode da do krive interpretacije grafičkih podataka dolazi zbog nedovoljnog polaganja važnosti pojmovima mala, srednja, nikakva, velika jer profesori ne upozoravaju učenika da je razlika između tih pojmova bitna kada se opisuje grafički prikaz. U ovom slučaju to se pokazalo od velike važnosti, jer je samo dvoje učenika ponudilo točan i precizan odgovor.

Pitanja NB1-2 i NB2-6 izdvojena su zbog distraktora koje sadrže. Pitanje NB1-2 provjerava drugu kognitivnu razinu, ali nije primjerno za prvi razred gimnazije. U prvom razredu uče se osnovne činjenice o virusima, a u drugom razredu virusi se dulje analiziraju i navode se bolesti koje uzrokuju. Prema Garašić (2012) ovakav tip pitanja koji nije primjeren za neki razred zbog nedovoljne dubine učeničkog znanja smanjuje ukupnu uspješnost pri rješavanju. Također Lukša (2011) napominje da riješenost ovakvih pitanja ovisi o nastavnicima i njihovom načinu strukturiranja gradiva te pridavanju važnosti određenim činjenicama koje će prenijeti učenicima. Osim toga, distraktori nisu primjereni za ovo pitanje, jer učenici nisu imali mogućnost čuti za sve navedene pojmove, a ako su i čuli ne znaju jesu li to DNA ili RNA virusi. Pri obradi nastavnih sadržaja vezanih za ljudsko tijelo trebalo bi se više orijentirati prema onome što je učeniku bitno za daljnju iskoristivost u životu, a ne navođenju pojmova i činjenica (Marbach-Ad i Sokolove, 2000). Garašić (2012) navodi da pristup nastavnika prema konkretnom kontekstu u osmom razredu u osnovnoj školi utječe na daljnji interes učenika za ove sadržaje. U pitanju NB2-6 većina netočnih odgovora (distraktora) temelji se na razumijevanju građe ljušturice kremenjašica, ali se pri tom koriste specifični termini. Pitanje bi dobilo na kvaliteti da je ponuđena slika koja se treba nadopuniti jer učenici ne razumiju princip građe ljušturice kremenjašica. Lukša (2011) navodi da učenici bolje i lakše pamte ako im se ponudi model koji moraju opisati svojim riječima. Točan odgovor je jako očit i ističe se, a jedan je distraktor potpuno neiskorišten.

Grgurić, I., , Begić, V., Bastić, M., Lukša, Ž., Radanović, I. 2017. Kvaliteta pitanja i uspjeh srednjoškolskih sudionika natjecanja iz biologije u znanju. Educ. biol. 3, 1, 32-56. 
Pitanja NB3-4 i NB3-20b su u jednom pogledu interdisciplinarnog karaktera. Pitanju NB3-4 umanjena je kvaliteta odabirom mjerne jedinice, jer se učenici koncentriraju na preračunavanje, a ne na bit pitanja koje je vrlo važno i korisno. Lukša (2011) i Garašić (2012) ističu veliku zabrinutost zbog učeničkog nerazumijevanja krvnog tlaka i njegovog utjecaja na organizam, anerazumijevanje se pripisuje integraciji s kemijom i fizikom uz utjecaj tlaka na tijelo. Učenici nemaju naviku povezivati nastavne sadržaje različitih predmeta i ne upotrebljavaju koncepte koje su učili na predmetima STEM područja da si lakše objasne predstavljeni biološki problem. Labov i suradnici (2010) ističu da u pitanjima koja su interdisciplinarnog karaktera, a obrađuju i sagledavaju se s jednog gledišta, stvaraju miskoncepcije koje je kasnije teško izbjeći. Preporuča se eksperiment pomoću kojega će učenici sami doći do rješenja koristeći znanje koje imaju iz svih predmeta uz integraciju znanja. Pitanje NB3-20b je povezano s fizikom i matematikom, a tijekom analize pitanja uočena je zabrinjavajuća činjenica da učenici ne posjeduju mogućnost predodžbe omjera. Većina učenika je prvi dio zadatka dobro riješila, dok je obrazloženje dobivenih podatka išlo puno teže. Međusobne ovisnosti i utjecaji oplošja, volumena i površine zbunili su učenike tijekom primjene tih veličina na eritrocite. To ukazuje na činjenicu da učenici imaju poteškoća kada veličine moraju opisati pomoću primjera. Najčešće krivo tumačenje odnosilo se na odnos volumena i površine, dok je oplošje većinom bilo dobro koncipirano. Ovakva pitanja bi trebala biti češća u pisanim provjerama, jer od učenika zahtijevaju da logički zaključuje i pretače ih u kritičko mišljenje pri formuliranju zaključka uz primjenu osnovnih koncepata STEM područja. Won i suradnici (2007) u svom istraživanju ističu da ovakvi problemi nastaju zbog nedovoljnog predznanja ili nerazumijevanja kemije i fizike te miskoncepcija koje mogu nastati zbog neodgovarajućeg objašnjenja iz udžbenika, ali i nastavnika.

Veliko slaganje procjena mladih nastavnika i nastavnika s duljim radnim stažem te slabo slaganje eksperata i obje grupe nastavnika, ukazuju na potrebu sustavne edukacije i različitih oblika cjeloživotnog obrazovanja koja će nastavnike pripremiti za sastavljanje kvalitetnih pitanja, ali ne samo na teoretskoj osnovi već kao podrška njihova rada s učenicima. Takva promišljanja potvrđuju zaključci Oleson i Hora (2013) da nastavnici tijekom rada u učionici razvijaju svoje profesionalne identitete te umjesto da slijepo modeliraju ponašanja svojih instruktora, često se oslanjaju na vlastita iskustva u nastavi. Najslabija povezanost procjene važnosti pitanja za propisani program i poticanje kritičkog mišljenja kod učenika između eksperata u sastavljanju pitanja i nastavnika potvrđuje izostanak sustavne primjene konceptualnog okvira u nastavi biologije kao što je uočeno i u prethodnim istraživanjima (Lukša, 2011). $\mathrm{U}$ odnosu na postignutu riješenost zadataka utvrđena je mala povezanost pitanja slabije kvalitete i srednja povezanost kvalitetnijih pitanja s procjenom riješenosti, što je još jedna potvrda o prihvatljivoj kvaliteti zadataka. Težina pitanja i kognitivna razina srednje su obrnuto proporcionalno povezane $s$ ostvarenom riješenosti kako bi se provjerom moglo dobro izlučiti najuspješnije učenike. Pritom bolja povezanost riješenosti i kvalitete pitanja potvrđuje važnost pripreme pitanja uz uvažavanje elemenata procjene kvalitete, a posebno primjene kritičkog razmišljanja u zadacima provjere konceptualnog razumijevanja i sposobnosti rješavanja problema. Takav rezultat ističe potrebu sustavnog usmjeravanja nastavnika prema poticanju kritičkog mišljenja učenika i njihova konceptualnog razumijevanja biologije. Manje razlike između procjena mladih nastavnika i eksperata u odnosu na nastavnike $s$ duljim radnim stažem, ukazuju da je inicijalna pouka tijekom studija uspješno usmjerila studente u procjeni elemenata kvalitete pitanja. Analiza utjecaja pojedinog elementa procjene ukazuje da najveći utjecaj na slaganje procjena prema iskustvu ima kategorija utjecaj pitanja na odgovor. lako zaključke usporedbe procjene kvalitete pitanja prema radnom stažu i iskustvu u sastavljanju pitanja prema odrednicama kvalitete

Grgurić, I., , Begić, V., Bastić, M., Lukša, Ž., Radanović, I. 2017. Kvaliteta pitanja i uspjeh srednjoškolskih sudionika natjecanja iz biologije u znanju. Educ. biol. 3, 1, 32-56. 
ograničava mali uzorak, ipak se na osnovu provedene analize mogu uočiti trendovi, koje svakako treba provjeriti u budućim istraživanjima.

\section{ZAKLUUČAK}

Uočava se tendencija da se učenici tijekom rješavanja zadataka u pisanoj provjeri na županijskoj razini natjecanja iz biologije usmjeravaju prema aktivnom opažanju i zaključivanju uz korištenje znanja usvojenih tijekom učenja biologije, a takav pristup pripremi pisanih provjera poželjan je i za pisane provjere u redovitoj nastavi. Prema provedenom istraživanju moguće je zaključiti:

pitanja su kvalitetom prihvatljiva, ali nedovoljno dobra za svrhu natjecanja u znanju te je neophodno poboljšati kvalitetu pitanja

srednja distribucija pitanja prema težini je zadovoljavajuća za potrebe natjecanja, ali treba voditi brigu da bude primijenjena u svakoj pisanoj provjeri, odnosno u pisanoj provjeri za natjecanje treba biti $10 \%$ laganih pitanja, 70 \% srednje teških pitanja i $20 \%$ teških pitanja

na kvalitetu najslabije riješenih pitanja najveći utjecaj ima važnost pitanja za struku, a autori takvim pitanjima posvećuju veliku pažnju u oblikovanju pitanja i njegovoj razumljivosti

najkvalitetniji zadaci ipak još nedovoljno potiču učenike u razmišljanju i konceptualnom povezivanju, a još veću pažnju treba usmjeriti na oblikovanje i razumljivost pitanja te smanjiti utjecaj samo logičkog zaključivanja učenika bez stvarne primjene znanja, što će se omogućiti usmjeravanjem učenika da pri rješavanju zadataka kritički promišljaju

s obzirom da se radi o natjecanju učenika na županijskoj razini, prihvatljiv je manji utjecaj potrebnog dodatnog učenja učenika da bi uspješno mogli riješiti pitanja na natjecanju, dok u natjecanjima na državnoj razini prihvatljiv može biti i srednji takav utjecaj, ali samo u svrhu konceptualnog proširivanja temeljnog znanja redovne nastave primjenjivog u rješavanju složenijih problemskih situacija predstavljenih u zadacima, a ne opterećivanju učenika memoriranjem dodatnih pojmova, kako bi se što bolje izlučili učenici kvalitetnog biološkog pomlatka

$\checkmark$ bolja povezanost riješenosti i kvalitete pitanja potvrđuje važnost pripreme pitanja uz uvažavanje elemenata procjene kvalitete, a posebno primjene kritičkog razmišljanja u zadacima provjere konceptualnog razumijevanja i sposobnosti rješavanja problema

$\checkmark$ potrebno je učenicima predstaviti tipove zadataka kakvi će se primjenjivati u natjecanju kako bi se mogli bolje pripremiti za njihovo rješavanje

$\checkmark$ sastavljači pitanja za natjecanje trebaju dosljednije slijediti upute o raspodjeli pitanja prema kognitivnim razinama u cijeloj pisanoj provjeri

$\checkmark$ pri sastavljanju najkvalitetnijih pitanja autori su veliku pažnju poklonili svim elementima poticanja razvoja prirodoslovne pismenosti kod učenika pri čemu nastoje da pitanja za poticaj razvoja prirodoslovne pismenosti učenicima ne budu uvijek preteška za rješavanje

autori nastoje da pitanja budu primjereno oblikovana i da ih učenici ne mogu rješavati samo uz pomoć logičkog zaključivanja, pri čemu su najbolja pitanja srednje razumljiva učenicima, a čemu bi ubuduće trebalo pokloniti više pažnje

autori pitanja trebaju ubuduće nastojati da se kod pitanja koja su tehnički dotjerana te time nemaju utjecaj na rješavanje, više pažnje pokloni usmjeravanju na poticanje prirodoslovne pismenosti, a posebno kritičkog mišljenja

$\checkmark$ ograničavajući čimbenik u pripremi zadataka je i usmjerenost kataloga natjecanja na nastavni program, koji je izrazito sadržajno orijentiran te bi bilo poželjno usmjeriti sastavljače da pri pripremi pitanja koriste konceptualni okvir i njemu pripadajuće ishode u okviru propisanog nastavnog programa Biologije

neophodno je uvesti znanstvenu recenziju ne prema razredima već prema znanstvenom polju znanstvenika koji recenzira pitanja za pisane provjere

nužno je da osim znanstvene provjere pitanja budu podvrgnuta i metodičkoj recenziji od osobe koja ima veliko iskustvo u pripremi zadataka na nacionalnoj razini, kao i njihovoj procjeni 
preporučuje se sastavljačima i recenzentima da procjene kvalitetu pitanja prema kriterijima stručne procjene kvalitete pitanja, kako bi se u potpunosti postigla svrha provjeravanja znanja učenika na natjecanju

nužno je organizirati modularno certificirano poučavanje malih grupa nastavnika u pripremi zadataka kontinuiranim radom s povratnim informacijama o pogreškama i napretku ali ne samo na teoretskoj osnovi već kao podrška njihova rada s učenicima, a takvo bi stručno usavršavanje bilo poželjno ne samo za sastavljače pitanja za natjecanje ili druge ispite na nacionalnoj razini, već i za pripremu svakodnevnih pisanih provjera u redovitoj nastavi biologije.

\section{METODIČKI ZNAČAJ}

Ovo istraživanje, kao i slična istraživanja s analizom pitanja u različitim pisanim provjerama znanja, trebalo bi pridonijeti promjeni pristupa u sastavljanju pisanih provjera na svim razinama školskog sustava. Potvrđena je vrijednost primjene stručne procjene kvalitete pitanja za potrebe sustavne analize, ali i kao preporuka da se koristi pri sastavljanju pitanja uz suradnju sustručnjaka. Izrada i analiza pisanih provjera zahtjeva dodatnu edukaciju nastavnika kao i kontinuirano, sustavno istraživanje i traženje načina za poboljšanje kvalitete provjere znanja učenika doprinijet će dobivanju jasnih, sustavih i smislenih povratnih informacija i za učenike i za nastavnike s ciljem poboljšanja procesa poučavanja.

\section{ZAHVALA}

Kvalitetu pitanja prema kriterijima stručne procjene provele su nastavnice i učiteljice biologije na čemu im se najljepše zahvaljujemo.

\section{LITERATURA}

Allen, D., Tanner, K. 2002. Approaches to cell biology teaching: questions about questions. Cell Biology Education, 1, 63-67. Andrilović, V., Čudina, M. 1985. Metode istraživanja u odgoju i obrazovanju. Školska knjiga, Zagreb.

AZOO 2014. Natjecanje iz biologije 2015. http://www.azoo.hr/index.php?option=com content\&view=article\&id=5429:natjecanje-iz-biologije2015-\&catid=89:biologija, preuzeto 20.09.2016.

Barksdale-Ladd, M. A., Thomas, K. F. 2000. What's at stake in high-stakes testing teachers and parents speak out. Journal of Teacher Education, 51, 5, 384-397.

Barmby, P., Kind, P. M., Jones, K. 2008. Examining changing attitudes in secondary school science. International Journal of Science Education, 30, 8, 1075-1093.

Braš Roth, M., Gregurović, M., Markočić Dekanić, A., Markuš, M. 2008. PISA 2006, Prirodoslovne kompetencije za život. Nacionalni centar za vanjsko vrednovanje obrazovanja - PISA centar, Zagreb.

Braš Roth, M., Gregurović, M., Markočić Dekanić, A., Markuš, M. 2010. PISA 2009, Čitalačke kompetencije za život. Nacionalni centar za vanjsko vrednovanje obrazovanja - PISA centar, Zagreb.

Braš Roth, M., Gregurović, M., Markočić Dekanić, A., Markuš, M. 2014. PISA 2013, Prirodoslovne kompetencije za život. Nacionalni centar za vanjsko vrednovanje obrazovanja - PISA centar, Zagreb.

Braš Roth, M., Markočić Dekanić, A., Markuš Sandrić, M. 2017. PISA 2015, Prirodoslovne kompetencije za život. Zagreb, Nacionalni centar za vanjsko vrednovanje obrazovanja - PISA centar.

Chang A. 2014. Statistics Toolkit (StatsToDo). Department of Obstetrics and Gynaecology, the Chinese University of Hong Kong. https://www.statstodo.com/index.php, pristupljeno rujan 2016.

Cindrić, M., Miljković, D., Strugar, V. (2010): Didaktika i kurikulum, IEP-D2,Zagreb

De Zan, I. 2005. Metodika nastave prirode i društva. Školska knjiga, Zagreb.

Flores, F., Tovar, M.E., Gallegos, L.. 2003. Representation of the cell and its processes inhigh school students: an integrated view. International Journal of Science Education, 25, 2, 269-286.

Garašić, D. 2012. Primjerenost biološkog obrazovanja tijekom osnovnog i gimnazijskog školovanja. Prirodoslovno-matematički fakultet Sveučilišta u Zagrebu, doktorska disertacija.

Garašić. D. Radanović. I.. Lukša. Ž. 2013. Usvojenost makrokoncepata biologije tijekom učenja u osnovnoj školi i gimnaziji. Metodike u suvremenom odgojno-obrazovnom sustavu. Milanović. D.. Bežen. A.. Domović. V. (ur.). Akademija odgojno-obrazovnih znanosti Hrvatske, Zagreb, 211-239.

George, R. 2006. A cross-domain analysis of change in students' attitudes toward science and attitudes about the utility of science. International Journal of Science Education, 28, 6, 571-589.

Grgin, T. (1994.): Školska dokimologija, Naklada Slap, Jastrebarsko.

HBD 2016. Natjecanje iz biologije 2015. Hrvatsko biološko društvo, http://www.hbd-sbc.hr/natjecanjaucenika/drzavno-natjecanje-mladih biologa/natjecanje-iz-biologije-2015/, pristupljeno 20.07.2015.

Higham, P. A., Arnold, M. M. 2007. How many questions should I answer? Using bias profiles to estimate optimal bias and maximum score on formula-scored tests. European Journal of Cognitive Psychology. 19, 4-5, 718-742.

Grgurić, I., , Begić, V., Bastić, M., Lukša, Ž., Radanović, I. 2017. Kvaliteta pitanja i uspjeh srednjoškolskih sudionika natjecanja iz biologije u znanju. Educ. biol. 3, 1, 32-56. 
Hopkins. K. D. 1998. Educational and psychological measurement and evaluation. Boston: Allyn \& Bacon.

Knight, J. K., Wood, W. B. 2005. Teaching More by Lecturing Less. Cell Biology Education. 4, 298-310.

Labov, J. B., Reid, A. H., Yamamoto, K. R. 2010. Integrated Biology and Undergraduate Science Education:A New Biology Education for the Twenty-First Century?, CBE-Life Sciences Education, 9, 10-16.

Lujan, H. L., DiCarlo, S. E. 2006. Too much teaching, not enough learning: what is the solution? Advances in Physiology Education, 30,17-22.

Lukša, Ž. 2011. Učeničko razumijevanje i usvojenost osnovnih koncepata u biologiji: doktorska disertacija. Prirodoslovnomatematički fakultet Sveučilišta u Zagrebu. 317. str.

Lukša, Ž., Radanović, I., Garašić, D. 2013. Konceptualni pristup poučavanju uz definiranje makrokonceptualnog okvira za biologiju, Život i škola, br. 30 (2): 156-171.

Lukša Ž., Radanović, I., Garašić, D. 2013. Očekivane i stvarne miskoncepcije učenika u biologiji. Napredak: časopis za pedagogijsku teoriju i praksu. 154(4): 527-548.

Lukša, Ž., Radanović, I., Garašić, D., Sertić Perić, M. 2016. Misconceptions of Primary and High School Students Related to the Biological Concept of Human Reproduction, Cell Life Cycle and Molecular Basis of Heredity. Journal of Turkish Science Education (TUSED), 13,3, 143-160.

Marušić, I. 2006. Nastavni programi iz perspektive učenika. U B. Baranović (Ur.), Nacionalni kurikulum za obvezno obrazovanje u Hrvatskoj: Različite perspektive. IDIZ. Zagreb.

Marbach-Ad, G., Sokolove, P. G. 2000. Can undergraduate biology students learn to ask higher-level questions? Journal of Research in Science Teaching, 37, 854-870.

MZOŠ 1995. Nastavni plan i program za gimnazije. Glasnik ministarstva prosvjete i športa, 11, 8-18.

Oleson, A., Hora, M.Z. 2013. Teaching the way they were taught? Revisiting the sources of teaching knowledge and the role of prior experience in shaping faculty teaching practices. High Educ., DOI: 10.1007/s10734-013-9678-9

Radanović, I., Ćurković, N., Bastić, M., Leniček, S., Furlan, Z., Španović, P., Valjak, M. 2010. Kvalitativna analiza ispita provedenih 2008. godine u osnovnim školama, Izvješće o projektu - Biologija, Nacionalni centar za vanjsko vrednovanje, Zagreb.

Radanović, I., Bastić, M., Begić, V., Kapov, S., Sumpor, D., Mustać A. 2013. Preporuke za autore i recenzente provjera natjecanja u znanju biologije. HBD. http://www.hbd-sbc.hr/wordpress/wp-content/uploads/2013/06/Preporuke-za-autore-irecenzente-natjecanja-20131.pdf. Preuzeto 31.7.2017.

Radanović, I., Garašić, D., Lukša, Ž., Pongrac Štimac, Z., Bastić M., Kapov S., Karakaš D., Lugarić S., Vidović M. 2015. Ispitni katalog za Državnu maturu iz Biologije. NCVVO, Zagreb. 53 str.

Radanović, I., Garašić, D., Lukša, Ž., Ristić-Dedić, Z., Jokić, B., Sertić Perić, M. 2016. Understanding of photosynthesis concepts related to students' age. Electronic Proceedings of the ESERA 2015 Conference. Helsinki. Finland. Science education research: Engaging learners for a sustainable future; Learning science: Conceptual understanding. Lavonen. J. Juuti. K.. Lampiselkä. J.. Uitto. A.. \& Hahl. K. (ur.). 1: 271-277.

Radanović I., Lukša Ž., Begić V., Bastić M., Gotlibović G., Kapov S., Pavunec S., Toljan M. 2017a. Sadržajna i metodološka analiza ispita državne mature iz Biologije školskih godina 2013./2014. i 2014./2015. NCVVO Zagreb, 101 str.

Radanović I., Lukša Ž., Pongrac Štimac Z., Garašić D., Bastić M., Kapov S., Kostanić LJ., Sertić Perić M., Toljan M. 2017b. Sadržajna i metodološka analiza ispita državne mature iz Biologije u školskoj godini 2015./2016. NCVVO Zagreb, 212 str.

Radanović,I., Lukša, Ž., Begić, V., Bastić, M., Garašić, D., Sertić Perić, M., Podrug, I. 2017c. Professional quality assessment of the Croatian state written exam in biology. - ESERA (European Science Education Researche Association), Dublin. Ireland.

Ristić - Dedić Z., Jokić, B., Šabić, J. 2011. Analiza sadržaja i rezultata ispita državne mature iz biologije. Institut za društvena istraživanja - Centar za istraživanje i razvoj obrazovanja, Nacionalni centar za vanjsko vrednovanje, Zagreb.

Simpson, M., Arnold, B. 1982. Availability of Prerequisite concepts for learning biology at certificate level. Journal of Biological Education 16,1, 65-72.

Usak, M., Prokop, P., Ozden, M., Ozel, M., Bilen, K., Erdogan, M. 2009. Turkish university students' attitudes toward biology: The effects of gender and enrolment in biology classes. Journal of Baltic Science Education, 8, 2, 88-96.

Vizek-Vidović, V., Rijavec, M., Vlahović Štetić, V., Miljković, D. 2003. Psihologija obrazovanja. IEP, Zagreb.

Won , J. A., Ko, Y.H., Paik, S. H. 2007. High School Science Teachers' and Students' Conceptions Related to Osmosis. Journal of The Korean Association For Research In Science Education. 27, 2, 144-152.

Grgurić, I., , Begić, V., Bastić, M., Lukša, Ž., Radanović, I. 2017. Kvaliteta pitanja i uspjeh srednjoškolskih sudionika natjecanja iz biologije u znanju. Educ. biol. 3, 1, 32-56. 